\title{
Anti-Inflammatory and Anticancer Properties of Birch Bark-Derived Betulin: Recent Developments
}

\author{
Hardeep Singh Tuli ${ }^{1, *}$, Katrin Sak ${ }^{2}{ }^{\mathbb{D}}$, Dhruv Sanjay Gupta ${ }^{3}$, Ginpreet Kaur ${ }^{3}$, Diwakar Aggarwal ${ }^{1}$, \\ Nidarshana Chaturvedi Parashar ${ }^{1}$, Renuka Choudhary ${ }^{1}$, Mukerrem Betul Yerer ${ }^{4}{ }^{\circledR}$, Jagjit Kaur ${ }^{5}$, \\ Manoj Kumar ${ }^{6}{ }^{\circ}$, Vivek Kumar Garg ${ }^{7}$ and Gautam Sethi ${ }^{8, *}$
}

1 Department of Biotechnology, Maharishi Markandeshwar (Deemed to be University), Mullana, Ambala 133207, Haryana, India; diwakaraggarwal@yahoo.co.in (D.A.); nidarshanachaturvedi@gmail.com (N.C.P.); renuka.ndri@gmail.com (R.C.)

2 NGO Praeventio, 50407 Tartu, Estonia; katrin.sak.001@mail.ee

3 Shobhaben Pratapbhai Patel School of Pharmacy and Technology Management, SVKM's NMIMS, Mumbai 40056, Maharashtra, India; dhruvg2507@gmail.com (D.S.G.); ginpreet.kaur@nmims.edu (G.K.)

4 Department of Pharmacology, Faculty of Pharmacy, Erciyes University, Kayseri 38039, Turkey; eczbetul@yahoo.com

5 ARC Centre of Excellence in Nanoscale Biophotonics (CNBP), Graduate School of Biomedical Engineering, Faculty of Engineering, The University of New South Wales, Sydney 2052, Australia; 1990jagjit@gmail.com

6 Department of Chemistry, Maharishi Markandeshwar University, Sadopur 134007, Haryana, India; manojraju27@gmail.com

Citation: Tuli, H.S.; Sak, K.; Gupta, D.S.; Kaur, G.; Aggarwal, D.; Chaturvedi Parashar, N.; Choudhary, R.; Yerer, M.B.; Kaur, J.; Kumar, M.; et al. Anti-Inflammatory and Anticancer Properties of Birch Bark-Derived Betulin: Recent Developments. Plants 2021, 10, 2663. https://doi.org/10.3390/ plants10122663

Academic Editors: In Jin Ha and Seok-Geun Lee

Received: 9 November 2021

Accepted: 29 November 2021

Published: 3 December 2021

Publisher's Note: MDPI stays neutral with regard to jurisdictional claims in published maps and institutional affiliations.

Copyright: (c) 2021 by the authors. Licensee MDPI, Basel, Switzerland. This article is an open access article distributed under the terms and conditions of the Creative Commons Attribution (CC BY) license (https:/ / creativecommons.org/licenses/by/ $4.0 /)$.
7 Department of Medical Laboratory Technology, University Institute of Applied Health Sciences, Chandigarh University, Gharuan, Mohali 140413, Punjab, India; garg.vivek85@gmail.com

8 Department of Pharmacology, Yong Loo Lin School of Medicine, National University of Singapore, Singapore 117600, Singapore

* Correspondence: hardeep.biotech@gmail.com (H.S.T.); phcgs@nus.edu.sg (G.S.)

\begin{abstract}
Birch tree bark-derived betulin has attracted scientific interest already for several centuries, being one of the first natural products identified from plants. However, the cellular events regulated by betulin and precise molecular mechanisms under these processes have been begun to be understood only recently. Today, we know that betulin can exert important anticancer activities through modulation of diverse cellular pathways. In this review article, betulin-regulated molecular signaling is unraveled and presented with a special focus on its participation in anti-inflammatory processes, especially by modulating nuclear factor- $\mathrm{kB}(\mathrm{NF}-\mathrm{kB})$, prostaglandin/COX, and nuclear factor erythroid2-related factor 2 (Nrf2)-mediated cascades. By regulating these diverse pathways, betulin can not only affect the development and progression of different cancers, but also enhance the antitumor action of traditional therapeutic modalities. It is expected that by overcoming the low bioavailability of betulin by encapsulating it into nanocarriers, this promising natural compound may provide novel possibilities for targeting inflammation-related cancers.
\end{abstract}

Keywords: birch bark; betulin; inflammation; cancer; NF-kB; Nrf2; nanocarriers

\section{Introduction}

Natural products have been a highly attractive source for different pharmacological substances and therapeutic agents for several decades, particularly for infectious diseases at $75 \%$ and cancer at $60 \%$ of new drugs are originated from different natural sources [? ? ? ]. In fact, several well-known anticancer drugs have been initially isolated from plants with at least nine plant-derived compounds approved for the use in clinical settings since 1961 [? ]. These substances include vinblastine and vincristine from the Madagascar periwinkle plant, paclitaxel from the bark of the Pacific yew (Taxus brevifolia) tree, podophyllotoxin from the roots of the mayapple plant (family Berberidaceae), and camptothecin from certain angiosperms [? ]. Considering that the incidence rate of new cancer cases is expected to continuously increase each year [? ? ? ? ? ? ? ] and many types of malignancies are 
still remained incurable, further devoted investigation into phytochemicals can provide potential novel leads for developing new anticancer drugs with higher efficiency and broader safety profile [? ? ? ? .

Betulin, a naturally occurring triterpene, is commonly derived from the bark of birch trees Betula L. [? ]. This compound was first isolated as a pure chemical substance already in 1788, being one of the first natural products identified from plants [? ]. Besides giving the tree its white color and thereby protecting birches from midwinter overheating by the sun [? ], a number of recent studies have shown that betulin is biologically active also in human beings, particularly against development of different tumors [? ]. Although the exact molecular mechanisms underlying anticancer action of betulin have still remained to be unraveled, they have been largely related to anti-inflammatory activities of this phytochemical [? ]. In this way, the role of betulin against inflammation-associated malignancies has been often demonstrated, describing its growth inhibitory and apoptosisinducing effects in a wide spectrum of human malignancies, including colorectal, gastric, liver, lung, breast, ovarian, cervical and prostate cancer cells [? ]. In this review article, the current preclinical knowledge about anti- inflammatory and anticancer properties of betulin is compiled and systematically presented, highlighting besides the bottlenecks also the potential solutions to move on to clinical trials.

\section{Chemistry of Betulin}

Chemically, betulin is a pentacyclic triterpenoid which is also known as betulinic alcohol (Figure ??) obtained from bark of white birch species found in northern latitude of world including Alaska, Canada, Europe, Russia and Asia [? ].

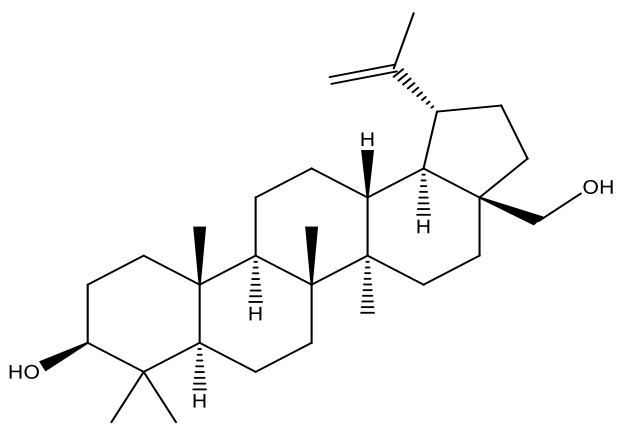

Figure 1. Structure formula of betulin.

Chemical modifications in betulin can be easily accomplished at positions C-28, C-3, and C-20 [? ]. Many reports have been found in literature disclosing the pathway for the synthesis of betulin's derivatives. Presence of the high content of betulin in white birch bark (up to $30 \%$ ) makes it suitable for the synthesis of biologically active derivatives of Betulin. Boryczka et al. in 2013 reported the synthesis of new interesting acetylenic derivatives of Betulin by treating a mixture of Betulin and pyridine in dry benzene [? ] with propargyl chloroformate (a), 2-butyn-1-yl chloroformate (b), 3-butyn-1-yl chloroformate (c), ethyl chloroformate $(\mathrm{d})$ respectively in dry benzene (Figure ??).

Betulinic acid is an important natural derivative which is formed by the oxidative reactions of betulin. Methanolic and ethanolic extractions of various plant parts are found to possess significant amount of betulinic acid [? ]. Betulinic acid can also be synthesized from betulin by a two-step chemical reaction. In first step oxidation of the C3 and C28 hydroxyls occurred followed by the reduction of betulonic acid (Figure ??) by using sodium borohydride [?]. 

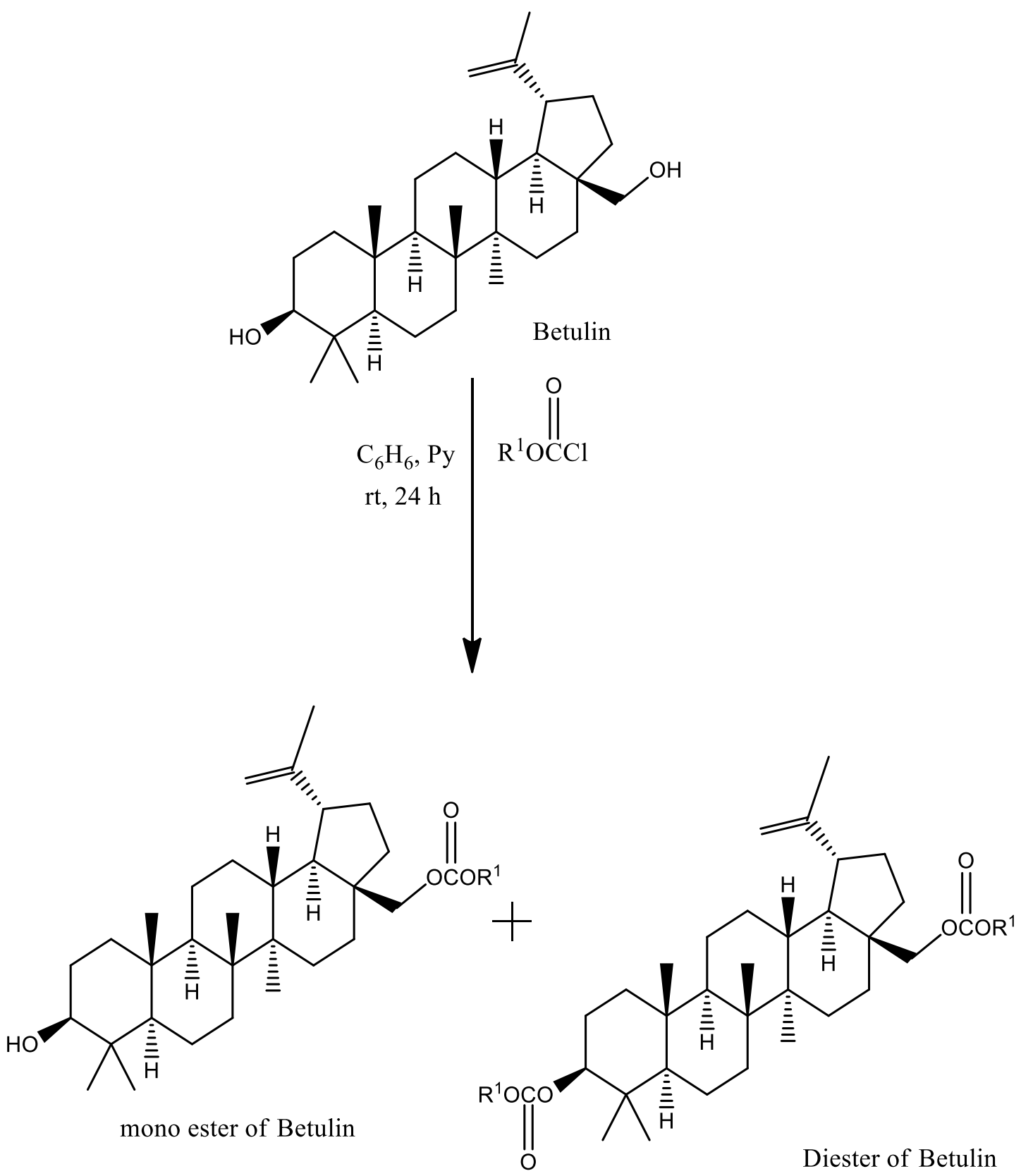
a. ${ }^{1}: \mathrm{CH}_{2} \mathrm{C} \equiv \mathrm{CH}$
b. ${ }^{1}: \mathrm{CH}_{2} \mathrm{CH}_{2} \mathrm{C} \equiv \mathrm{CH}$
c. ${ }^{1}: \mathrm{CH}_{2} \mathrm{C} \equiv \mathrm{CCH}_{3}$
d. ${ }^{1}: \mathrm{CH}_{2} \mathrm{CH}_{3}$

Figure 2. Synthesis of acetylenic derivatives of Betulin. 


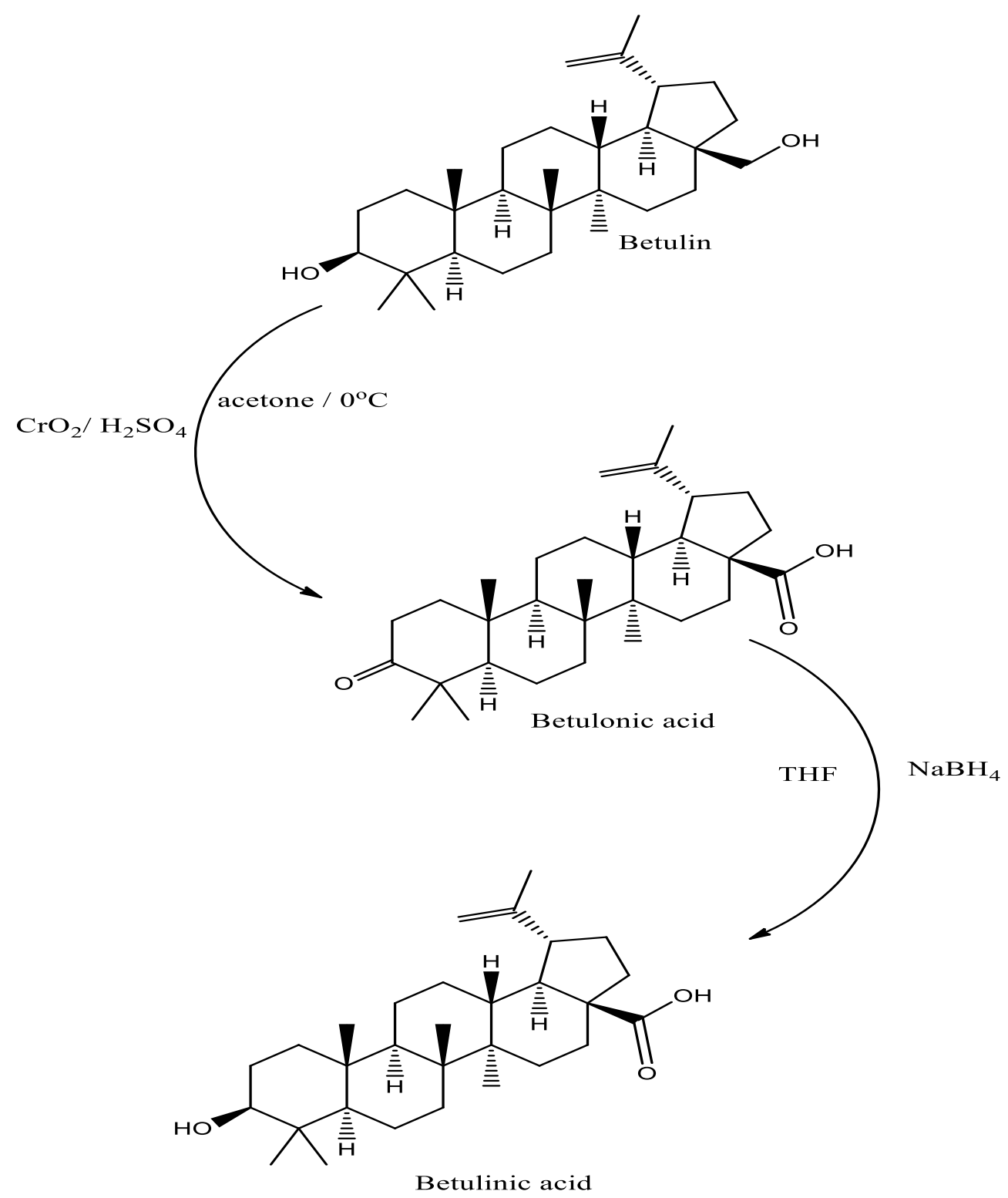

Figure 3. Synthesis of betulinic acid from Betulin by Jones oxidation followed by reduction.

\section{Absorption, Metabolic Conversion, and Bioavailability of Betulin}

Betulin exhibits enormous pharmacological potential [? ? ? ], owing to its relatively small size and specific cytotoxic actions against tumor cells. This has encouraged research on the molecule, aiming to highlight its advantage as compared to conventional therapeutic agents.

Experimental studies carried out on human and rat hepatic microsomes and cytosol indicated that two major biotransformation pathways for betulin are glucuronidation and sulfonation [? ]. The data obtained from studies in rat models showed that hUGT1A3 and $1 \mathrm{~A} 4$ were the main hepatic enzymes responsible for the formation of possibly a C3hydroxyl betulin glucuronide, while hSULT2A1 (responsible for the conversion of betulin into betulin sulphate I and II) was the main isoform involved in sulfonation. In human systems, glucuronidation occurs hepatically and extra-hepatically (in the gastrointestinal tract), and the same enzymes as rat models being predominant in catalyzing the reactions. One betulin glucuronide and two betulin sulfates were yielded at the end of the metabolism process [?]. 
In vivo studies have shown that the carbon-carbon double bond and hydroxy functional group are the main metabolism sites for betulin. The compound undergoes demethylation, dehydroxylation, deoxidization, dehydration as a part of the phase- 1 metabolic reactions, followed by conjugation reactions with cysteine, sulfate, taurine and N-acetylcysteine as a part of phase- 2 metabolism. Metabolites are obtained at each stage, as a product of the reactions. A total of 62 metabolites of betulin have been studied, a majority of which are obtained from phase-1 biotransformation [? ].

An experimental study has demonstrated the modulation of mitochondrial membranes, in case of colon and prostate cancer, which enhances the uptake of membrane proteins and expression of cytochrome c oxidase. Anti-cancer agents such as betulin may exert therapeutic effects by targeting the modified membranes, owing to the high affinity of betulinic acid to the lipid monolayers present on the membranes. This mechanism may inhibit the growth and multiplication of cancerous cells [? ].

Betulin and its product of oxidation, betulinic acid show poor aqueous solubility owing to their structure. Hence, various derivatives, such as amino acid esters, have been synthesized to improve bioavailability and delivery to target tissues [? ]. Additionally, various 3-modified derivatives have been synthesized, which show promising ADME parameters and are more hydrophilic. These derivatives showed hydrogen bond acceptor (HBA) and hydrogen bond donor (HBD) values lying in the required range, along with low TPSA values, which facilitate delivery across the blood-brain barrier. As these derivatives show good transport properties, they may be harnessed for the treatment of neoplasms of the central nervous system [? ]. These derivatives are synthesized with the purpose of enhancing the therapeutic potentials of betulin.

\section{Anti-Inflammatory Mechanisms Involved in Anticancer Action of Betulin \\ 4.1. NF-kB-Mediated Signaling}

NF- $\mathrm{BB}$ is known to induce the expression of a diverse range of inflammatory genes that are further found to modulate the transcriptional rate of various cytokines and chemokines (interferons, interleukins, lymphokines, tumour necrosis factor) [? ? ? ]. In addition, NF- $\mathrm{kB}$ displays a promising role in modulating the cancer cell survival, and differentiation signaling cascade [? ? ? ]. Currently a vast amount of research is carried on cancer treatment therapies [? ? ] however, there are still some issues to be solved such as chronic inflammatory micro environment of tumor and high mortality rates. Therefore, the researchers have concentrated on developing the anti-inflammatory agents that could successfully treat cancer without causing any or minimal side-effects [? ? ? ]. One answer to this problem is to use of the anti-inflammatory phytochemicals such as betulin for the cancer treatment. Betulin has proven to possess anti-cancerous and anti-inflammatory properties against pancreatic, gastric, lung, ovarian [? ], melanoma cells [? ], and nervous system carcinomas [? ]. In addition, its cytotoxic effect on normal cells was lesser as compared towards the cancer cells [? ? ]. It affects the expression of NF- $\mathrm{KB}$ and triggers a diverse range of cellular mechanisms like cell-cycle arrest, cell viability inhibition, apoptosis induction, invasion/migration inhibition, and anti-angiogenesis (Figure ??). The tumors are formed in the body when the dynamic balance between the cell death and cell proliferation is disturbed, and excess of cell proliferation is caused. Therefore, apoptosis induction of the affected cells could be a good choice of treatment of the cancerous cells.

Apoptosis or programmed cell death is the mechanism of the cells to remove the superfluous, damaged, and defective cells [? ? ] through release of cytochrome c and activation of caspase- 9 or activation of caspase- 8 via pro-apoptotic receptors [? ? ? ]. The cancerous cells overexpress the anti-apoptotic proteins (Bcl-2 and XIAP) and betulin targets them to express its anti-cancerous properties [? ] by generation of reactive oxygen species (ROS). In a study, it was found that the gastric cancer SGC7901, MDA-MB-231 breast cancer, and colon carcinoma (Caco 2) cell growth was inhibited by betulin as it triggered mitochondrial release of cytochrome c, mitochondrial translocation of Bak, and Bax, and 
down-regulation of NF-kB p50 and 65, IKK $\alpha$ and $\beta$, ICAM- 1 and bcl-2 [? ? ? ]. Therefore, betulin can be used as an anti-cancerous agent for various types of cancers.

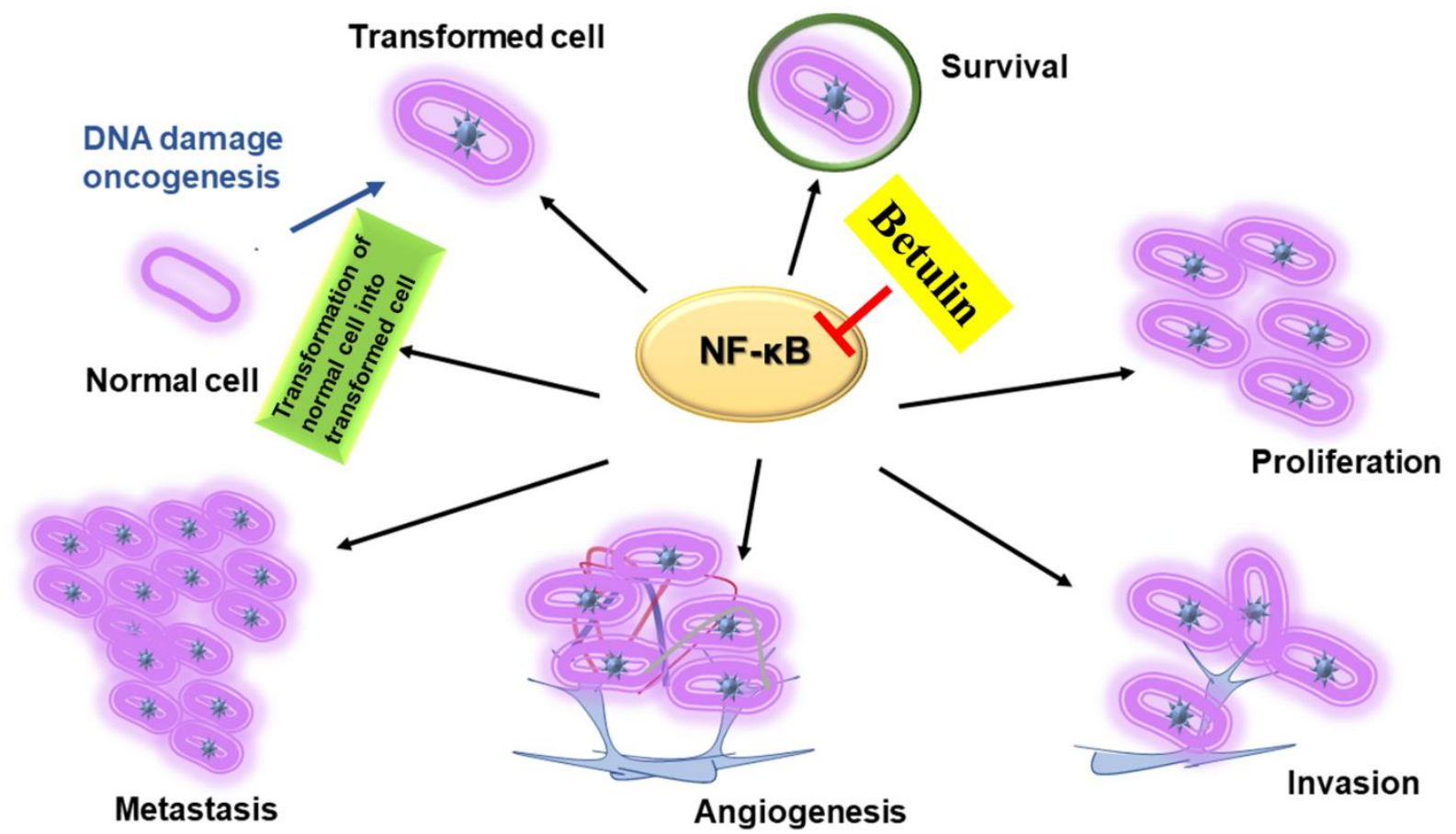

Figure 4. Role of betulin in inhibiting NF-kB mediated inflammatory mechanisms involved in the transformation of normal cells to cancer cells.

\subsection{Prostaglandin/COX-2-Regulated Inflammatory Events}

For numerous inflammatory pathways, the arachidonic acid (AA) acts as one of the most important metabolic precursor [? ? ]. The membrane bound AA cleaves from the phospholipids after the activation of phospholipase A2 (PLA2) by external and internal factors which gets available to various inflammatory events such as lipoxygenase, cytochrome P-450 monooxygenase and cyclooxygenase pathway [? ]. In mammals, the most comprehensively studied inflammatory pathway is cyclooxygenase pathway, which begins with AA conversion to $\mathrm{PGH}_{2}$ (substrate for prostaglandin) due to the action of prostaglandin G/H synthase commonly referred as cyclooxygenases [? ? ]. The COX-1 and COX-2 are the isoenzymes of cyclooxygenase enzymes. COX-1 acts as a housekeeping enzyme, as it is constitutive in nature and expressed in various parts of the body. In addition to this, it also carries out numerous physiological functions. Studies on mice revealed that COX-1 also plays a crucial role in development and progression of inflammation [? ? ? ?].

On the other side, COX-2 is mainly induced in response to various endogenous and exogenous stimulus such as cytokines (tumor necrosis factor $\alpha$ (TNF- $\alpha$ ), interleukins (IL-1 and IL-6), tumor promoters (v-src, v-Ha-ras, and Wnt)) and stress [? ? ]. It is mainly responsible for maintenance of inflammatory event after the initiation of inflammatory acute phase with COX-1 [? ]. Although COX-2 shows the structural similarity with COX-1, its enzymatic activity pattern is quite different due to prostaglandin-endoperoxide synthase 2 (PTGS-2) gene. After the induction of COX-2, there is excessive production of $\mathrm{PGE}_{2}$ along with other prostaglandins, which increases the vascular permeability and lowers the pain threshold. The physiological functions like blood pressure and immune response are maintained by $\mathrm{PGE}_{2}$, but in some pathological conditions more than 10-fold increase in the level of $\mathrm{PGE}_{2}$ concentration leads to serious complications [? ]. Controlled level of COX-2 enzyme production plays a crucial role in the physiological protective response to tissue injury. However, if uncontrolled enzyme production occurs, it can pro- 
mote angiogenesis and tumor invasiveness and ultimately causes inflammatory-induced carcinogenesis [? ? ? ? ].

For decades, traditional methods using natural products were used as medicines for treating numerous diseases [? ]. There are evidences of using these as remedies from pre historic times for all sorts of inflammatory diseases. Since, COX-2 is responsible for inflammatory events through $\mathrm{PGE}_{2}$ production and its uncontrolled level can cause carcinogenesis. Therefore, it is widely accepted that natural product having potential to inhibit COX-2 and $\mathrm{PGE}_{2}$ expression, will exhibit anti-inflammatory and anti-cancerous activities. Numerous triterpenoids such as betulin (B) and betulinic acid (BA) (the oxidation product of Betulin) isolated from botanical sources play an important role in inflammation reduction and exhibit anti-cancerous properties by targeting COX-2 and PGE 2 . These can induce antiinflammatory, tumor-differentiating, proliferation-arresting, and apoptotic effects based on the usage of their dose administered [? ]. Recent study on immunopharmacological activity of betulin revealed that it has a potential use in inflammation-associated carcinogenesis [? ]. The derivatives of betulin can also inhibit IFN- $\gamma$ and modulate COX-2 expression [? ]. Previous studies reported that betulinic acid can inhibit the cyclooxygenase pathway by reducing the synthesis of prostaglandins $\left(\mathrm{PGE}_{2}\right)$ and attenuate the inflammation in response of stimuli [? ? ? ]. Study on betulinic acid isolated from the Dillenia serrata also revealed the same that betulinic acid can modulate the activity of COX-2 and inhibit the $\mathrm{PGE}_{2}$ release [? ]. This COX-2-mediated inhibition of prostaglandin by betulin and betulinic acid controls the cell proliferation, angiogenesis, invasion and metastasis [? ]. Collectively, based on evidence in the literature it can be stated that betulin and its oxidation product betulinic acid induces its potent anti-inflammatory and anti-cancerous effects by blocking COX-2-mediated NF-kB pathway mechanisms [? ? ? ]. They can control the inflammation-induced cancer by inhibiting proliferation, invasion, metastasis, angiogenesis and inducing apoptosis, but more clinical investigations are required in order to support the proposed COX-2 inhibitory mechanism by betulin and betulinic acid (Figure ??).

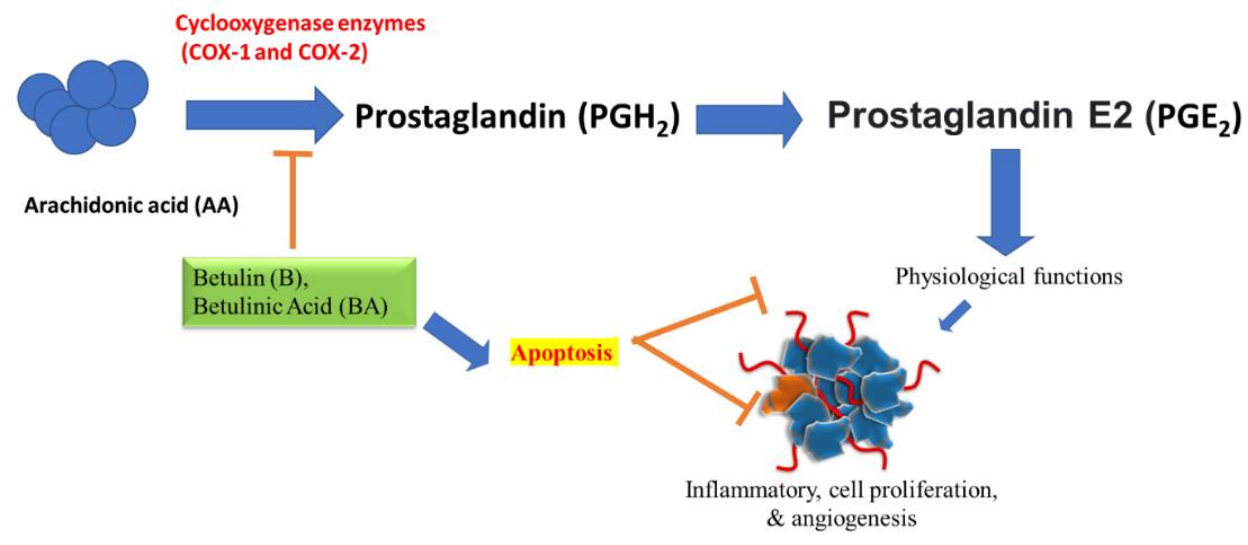

Figure 5. Action of Betulin (B) and Betulinic Acid (BA) on cyclooxygenase enzymes (Cox-1 and Cox-2) which convert the arachidonic acid to prostaglandins. Inhibition of prostaglandin $\mathrm{PGE}_{2}$ derived from Cox-2 by blocking its pathway through Betulin (B) and Betulinic Acid (BA) leads to inhibition of angiogenesis, proliferative invasion.

\subsection{Nrf2-Associated Signaling}

Betulin has been associated with its antiinflammatory effect over different cellular mechanisms including the nuclear factor erythroid 2-related factor 2 (Nrf2), a critical transcriptional activator for antioxidative responses (Figure ??). Nrf2 is a transcription factor that regulates an adaptive cellular defense response to oxidative stress and inflammation [? ? ]. It plays a crucial role in cellular redox homeostasis coordinating the induction of over 250 genes, including those encoding antioxidant and phase 2 detoxifying enzymes and related proteins, such as NADPH, quinine oxidoreductase 1 (NQO1), heme oxygenase-1 (HO-1), $\gamma$-glutamyl cysteine synthetase catalytic subunit (GCLC) and modifier subunit (GCLM) [?]. 


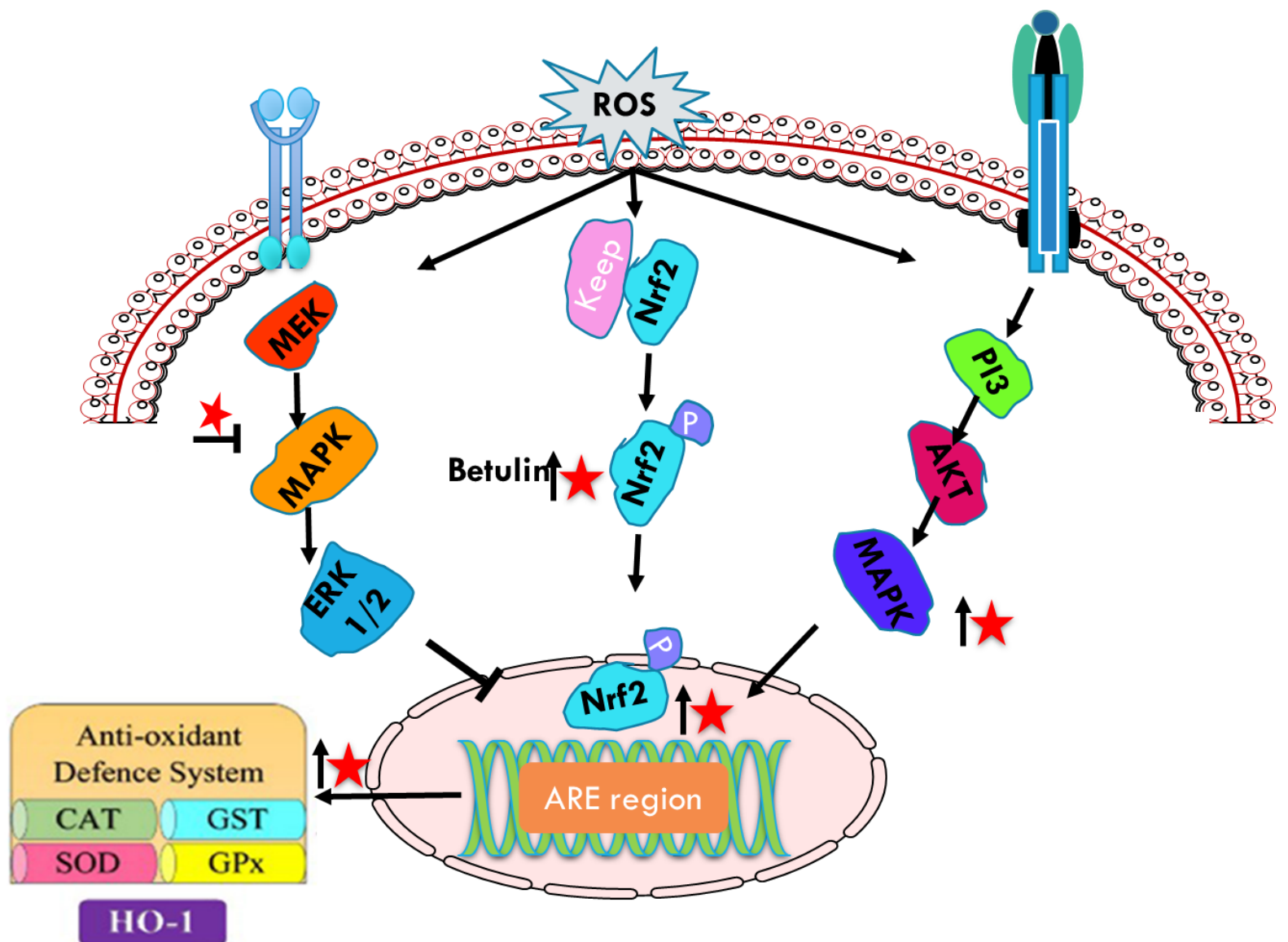

Figure 6. Schematic representations of betulin (represented as red star) mediated modulation (upregulation $\uparrow$, downregulation $\downarrow$ ) of Nrf 2 phosphorylation and anti-oxidant defense system.

Phosphorylation of Nrf2 at serine and threonine residues by upstream kinases, such as protein kinase $\mathrm{C}$, phosphatidylinositol-3-kinase/Akt (PI3K/Akt), and mitogen-activated protein kinase (MAPK), facilitates the release of Nrf2 from Keap1, a repressor molecule that facilitates Nrf2 ubiquitination [? ]. Nrf2 phosphorylation regulating the cellular responses to oxidative stress and inflammation is also regulated by AMP-activated protein kinase (AMPK), a heterotrimeric serine/threonine kinase [? ]. Activated Nrf2 quickly translocates from the cytoplasm into the nucleus to regulate gene expression. Nrf2 is anchored within the cytoplasm by Kelch-like-ECH-associated protein 1 (Keap1) before ubiquitarian. AMPK is also associated with PI3K/Akt pathway that has been shown to be regulated with AMPK. Furthermore, AMPK increases the phosphorylation of glycogen synthase kinase 3 beta (GSK3 $\beta$ ) inhibition [? ]. Nrf2 signaling has been implicated as an important target for averting DMBA-induced mammary cancer via augmented expression of MAPKs, Keap1, ARNT, AhR, and CYP1A1 [? ]. Therefore, strong antioxidant behavior of betulin by Nrf2 mediated MAPKs oxidative stress could be considered to inhibit cancer proliferation. Ci et al. [? ] has shown that betulin increased Nrf2-targeted antioxidant enzymes, in a dose and time dependent manner in LPS and endotoxin induced inflammatory responses in vitro and in vivo. Treatment with betulin increased Nrf2 translocation from cytoplasm to nucleus and downregulated the expression of the Keap1 protein in a dose-dependent manner. Furthermore, betulin attenuated LPS-induced inflammatory mediators (iNOS and COX-2) and MAPK inflammatory signaling pathway upregulating the HO-1 and NQO1, and downregulating the iNOS and COX-2 revealing that its anti-inflammatory effect is strongly coordinated with Nrf2 signaling pathways. Furthermore, betulin pretreatment reduced the increased levels of JNK, ERK, p38 and AKT phosphorylation in LPS induced macrophages. 
Activation of Nrf2 by triterpenoids induces the expression of phase 2 detoxifying and antioxidant enzymes such as NQO1 and HO-1, known enzymes which can protect cells or tissues against various toxic metabolites [? ]. Bai et al. [? ] has revealed that betulinic acid attenuates impairments of aortic contraction and relaxation in LPS-challenged rats by activating Nrf2-regulated anti-oxidative pathways.

Nrf2-mediated anti-inflammatory response is thought to be ROS-dependent, however a direct inhibitory effect of Nrf2 on the recruitment of RNA polymerase II, preventing the transcription of genes coding for the proinflammatory cytokines IL-1 $\beta$, IL-6 [? ? ? ], which is also important for the viral infections including Covid-19 [? ? ]. Activation of Nrf2 signaling pathway in phagocytic cells improved their anti-viral [? ], and anti-bacterial functions [? ]. Furthermore it has been noted that in macrophages regulating the Nrf2 mechanisms in bacterial infections is very important to control the inflammation [? ]. The most common Nrf2 nutrients has been listed by Iddir et al. [? ] including flavonoids and terpenoids [? ] and betulin has also been shown to act through Nrf2 signaling which deserves further investigation on Covid-19.

\section{Betulin as a Treatment Strategy for Cancer}

To design effective cancer treatment strategy, it is essential to understand the interactions of natural bioactive molecules with the recognized cellular targets. Several anti-cancer agents have been known to mediate both intrinsic (mitochondrial) as well as extrinsic (Fas/FasL) apoptotic cell death in cancer cells [? ? ]. Previous studies have suggested the role of bioactive natural molecules to arrest cell cycle by regulating the expression of cyclin-dependent kinases (CDKs) [? ? ]. In addition, the expression of metastatic as well angiogenesis proteins including matrix metalloproteinases (MMPs) and VEGF have also been down-regulated by the action of such bioactive metabolites [? ? ]. Furthermore, the anti-tumor aspect of natural metabolites can be correlated with their inhibitory effects on various inflammatory mediators (IL-6, IL-8, IFN- $\gamma$, iNOS, COX-2, and TNF- $\alpha$ ) [? ? ? ]. Therefore, exploring the mechanistic insight of bioactive molecules will help us to understand the biology of cancer and to investigate novel anti-cancer strategies in the near future [? ]. For instance, researchers have investigated the interaction of tumor cells with their microenvironment to develop promising anti-cancer strategy. Modulations of expression/activity of TNF- $\beta-$, NF- $-\mathrm{B}, \mathrm{MMP}-9, \mathrm{CXCR} 4, \mathrm{Ki}-67, \beta 1$-integrin, and caspase-3 could be a promising strategy for tumor control. Therefore, suppression of proinflammatory molecules by using natural agents can inhibit the cancer growth, survival, and metastasis [? ?].

\subsection{Co-Effects of Betulin with Standard Anticancer Therapies}

Secondary metabolites or natural compounds found ubiquitously distributed in different plant types have been documented to potentiate standard chemo-preventive measures used for cancer treatment [? ? ]. Such combinatorial or synergistic approaches exhibit remarkable efficacy in cancer therapy due to their multi-targeted actions, minimum sideeffects with little or no drug resistance and lack of considerable toxicity [? ? ? ? ?. Betulin when used in combination with a gamma-cyclodextrin derivative in melanoma B164A5 cells, the combinatorial therapy was found to reduce the cell proliferation, and induced differentiation and cell death [? ]. Further, combination strategy using betulinic acid and its derivatives in combination with radiation therapy on human malignant glioma cell lines has shown slightly enhanced effects on the radiosensitivity of malignant glioma cells [? ]. In addition, few studies have shown to have an additive effect of the compound in combination with irradiation on growth inhibition in melanoma [? ] and head and neck squamous cell carcinoma (HNSCC) cell lines [? ]. Moreover, in one of the studies, the efficacy of 5-fluorouracil (5-FU) and betulinic acid (BA) combination on ovarian carcinoma cells was studied and the results demonstrated increased sub-G1 cell population, increased rate of cell apoptosis and morphological changes in mitochondrial membrane. Therefore, the combinatorial therapy was found to be a promising strategy for the treatment of ovarian 
carcinoma [? ]. Furthermore, the study was conducted to explore the interactions between the natural compound and tumor necrosis factor-related apoptosis-inducing ligand of APO2, also known as TRAIL, in liver cancer cells and a synergistic effect of betulinic acid and APO2 combination on apoptosis induction in liver cancer cells was observed [? ]. Additionally, the compound also showed synergistic effects with taxol to induce breast cancer cells G2/M checkpoint arrest and apoptosis induction, but had little cytotoxicity effects on normal mammary epithelial cells [? ]. Combination treatment of the compound with ginsenoside Rh2 (G-Rh2) synergistically induced apoptosis in human cervical adenocarcinoma (HeLa), human lung cancer A549, and human hepatoma HepG2 cells by enhancing cleavage of caspase- 8 and $\mathrm{Bid}$ [? ]. Likewise, studies have also shown that betulinic acid along with other triterpenes, especially Japanese apricot extract, are effective supplements for increasing the chemotherapeutic effect of 5-fluorouracil on esophageal cancer [? ]. In conclusion, betulin and its derivatives like betulinic acid could prove to be promising treatment agents in various cancer types and a combination of the natural compound with different chemotherapeutic drugs seems to be beneficial.

\subsection{Role of Nanotechnology in Delivery of Betulin to Target Tissues}

Despite poor aqueous solubility, triterpenoids such as betulin have gained interest in the arena of nanotechnology on account of their potent cytotoxic properties. Formulating these compounds as nanopharmaceuticals additionally helps to enhance systemic bioavailability and stability of such phytoconstituents [? ? ]. Betulin was first encapsulated in liposomes by Mullauer et al., that could be used for the amelioration of colon and lung cancer tumors [? ]. More recently, Liu et al., formulated polyethylene-glycol modified liposomes of Betulinic acid, which showed promising in vivo results [? ].

The formulation of liposomes has a two-fold impact: enhancement of solubility as well as increasing the affinity of the agent to tumor cells, which enhances the permeation, and thereby efficacy of the molecule. Liposomes containing betulinic acid and a biosurfactant mannosylerythritol lipid-A (MEL-A) have been observed to trigger early-stage apoptosis of HepG2 cells, which in turn blocks cell division, thereby arresting tumor growth [? ]. In addition to this, micellar systems have been formulated to improve the delivery of betulin to target cells. Loading co-polymeric Soluplus micelles with betulinic acid has been seen to inhibit angiogenesis, DNA replication and tumor growth in vivo, specifically for breast cancer cells [?].

In relation to nanoemulsions, Dehelean et al., formulated a nanoemulsion of betulinic acid by high-pressure homogenization, using flax-seed oil as the oil phase [? ]. The antineoplastic effects of betulinic acid were assessed in vivo by Tan et al., using nanoparticles of betulinic acid, establishing that the magnetic nanoparticles may facilitate improved entry of the drug into cells [? ]. betulinic acid was also incorporated into a $\gamma$-cyclodextrin complex, thus allowing studies of betulinic acid delivery using cyclodextrin inclusion complexes [? ].

In a study, liquid crystalline nanoparticles of betulinic acid were formulated, helping to expand its therapeutic potential. The objective of such experiments is the formulation of theranostics, for drug delivery to specific, targeted tissues. Betulinic acid, in combination with manganese, was administered to mammalian breast cancer cell lines, as they demonstrate a synergistic effect. The formulation passed the biosafety test, carried out on embryonic hepatic cell lines, thus establishing its safety in biological systems. The apoptosis of MDA-MB-231 cells was seen by the onset of oxidative stress, as well as the exertion of an anti-inflammatory action [? ]. In an attempt to improve the oral bioavailability of betulinic acid, incorporation into poly(lactic-co-glycolic acid) (PLGA) has been reported to exert a preventive action against hepatocellular carcinoma (HCC) [? ].

Silver-based nanoparticles have been used as drug-delivery agents owing to their surface properties and mild cytotoxic properties, which make them potent anti-cancer agents. Based on data obtained from pre-clinical research, the usage of betulin in conjunction with silver nanocolloids (uncoated as well as PEG-coated) has shown efficacy in inhibiting the proliferation of HepG2 and A549 cells [? ]. Cyclic $\beta$-glucans may be used for encapsulating 
betulinic acid, owing to their ability to form complexes and dose dependent antioxidant property. In-silico studies have demonstrated a synergistic interaction, thereby potentiating the anti-neoplastic properties of betulin [? ].

These studies have yielded promising in vitro data, indicating the potential for usage of these nanotechnology systems in humans, as they help to combat some of the drawbacks of naturally derived triterpenes like betulin. Undertaking clinical trials would further improve the understanding of the therapeutic potentials and efficacy of betulin, thereby aiding management of neoplasms and various disorders with afflicted inflammatory pathways.

\subsection{Safety Issue of Betulin}

The most important aspect of any novel drug candidate is its safety on normal healthy tissues, allowing to elaborate the optimal dosage schemes with minimal adverse reactions [? ? ]. Animal studies have shown no toxic symptoms and good tolerability of triterpene extract, being administered either intraperitoneally to rats $(540 \mathrm{mg} / \mathrm{kg}$ for 28 days) or subcutaneously to beagle dogs ( $300 \mathrm{mg} / \mathrm{kg} /$ day for 28 days). Moreover, subcutaneous administration of betulin to male and female dogs resulted in a maximum plasma level of $325 \mathrm{ng} / \mathrm{mL}$ four weeks after treatment [? ]. Also, betulin was shown to reveal no mutagenic activity by Salmonella/microsome assay, again proving its potential safety [? ]. In addition, clinical trials with topical application of betulin-based Oleogel-S10 displayed well tolerability and safety of this treatment for patients with actinic keratoses [? ], epidermolysis bullosa [? ] or burn wounds [? ]. Although all these data clearly show the general safety of betulin and encourage further pharmacological and pharmaceutical studies using this natural compound (????), recently published results still demonstrate cytotoxicity of betulin in fish (BF-2) and murine fibroblasts (NIH/3T3) at doses similar to the $\mathrm{IC}_{50}$ values previously measured for malignant cells [? ]. Therefore, further thorough research on the safety of betulin is needed, verifying the selectivity of cytotoxic action of this compound towards cancerous cells.

Table 1. Anticancer effects of betulin and betulinic acid based on in vitro studies.

\begin{tabular}{|c|c|c|c|c|c|}
\hline Type of Cancer & Cell Lines & Effects & Mechanisms & Concentration & References \\
\hline Leukemia & Lucena 1 and K562 & $\begin{array}{l}\text { Blocking of the efflux } \\
\text { mediated by P-gp }\end{array}$ & $\begin{array}{l}\uparrow \text { restore sensitivity to doxorubicin in } \\
\text { Lucena } 1 \text { cells, did not exhibit } \\
\text { erythrocyte hemolysis }\end{array}$ & $0.39-50 \mu \mathrm{M}$ & [?] \\
\hline Myeloma & RPMI 8226 & Induces apoptosis & $\begin{array}{c}\downarrow \text { proliferation, migration and invasion } \\
\text { by tumor cells, } \downarrow \text { bcl- } 2, \uparrow \text { bax, } \downarrow \text { cyclin D1, } \\
\text { No change in CREB phosphorylation, }\end{array}$ & $\begin{array}{c}0,2.5,5,10 \text { and } \\
25 \mu \mathrm{M}\end{array}$ & [?] \\
\hline $\begin{array}{l}\text { Human T-cell } \\
\text { leukemia }\end{array}$ & Jurkat E6.1 & Induces apoptosis & $\begin{array}{c}\downarrow \text { proliferation, migration and invasion } \\
\text { by tumor cells, } \downarrow \text { bcl- } 2, \uparrow \text { bax, } \downarrow \text { cyclin D1, } \\
\text { No change in CREB phosphorylation, } \\
\text { Amounts of the CREB protein, and } \\
\text { ERK1/2, Akt, CaMKII kinases remained } \\
\text { unchanged }\end{array}$ & $\begin{array}{c}0,2.5,5,10 \text { and } \\
25 \mu \mathrm{M}\end{array}$ & [?] \\
\hline Glioma & T98G and C6 & Induces apoptosis & $\begin{array}{c}\downarrow \text { cell viability/survival and proliferation, } \\
\downarrow \% \text { age of T98G cells in G1 phase, } \uparrow \text { in } \\
\text { cell number in S phase, significant } \\
\text { activation of caspase } 3\end{array}$ & $\begin{array}{l}0.0-25 \mu \mathrm{M} \text { for } \\
\text { EB5 or } 0.0-50 \mu \mathrm{M} \\
\quad \text { for } \mathrm{EB} 25 / 1\end{array}$ & [?] \\
\hline Osteosarcoma & HOS and MG-63 & Induces autophagy $\downarrow \uparrow$ & $\begin{array}{c}\uparrow \text { LC 3-II, } \uparrow \text { phospho-Akt (Ser473), } \downarrow \\
\text { activation of mTOR }\end{array}$ & $\begin{array}{l}0,0.5,1,2,4,5,10 \\
\quad \text { and } 20 \mu \mathrm{M}\end{array}$ & [?] \\
\hline Medulloblastoma & TE671 & Induces apoptosis & $\begin{array}{c}\downarrow \text { proliferation, migration and invasion } \\
\text { by tumor cells, } \downarrow \text { bcl- } 2, \uparrow \text { bax, } \downarrow \text { cyclin D1, } \\
\text { No change in CREB phosphorylation, } \\
\text { Amounts of the CREB protein, and } \\
\text { ERK1 } 2 \text {, Akt, CaMKII kinases remained } \\
\text { unchanged }\end{array}$ & $\begin{array}{c}0,2.5,5,10 \text { and } \\
25 \mu \mathrm{M}\end{array}$ & [?] \\
\hline
\end{tabular}


Table 1. Cont.

\begin{tabular}{|c|c|c|c|c|c|}
\hline Type of Cancer & Cell Lines & Effects & Mechanisms & Concentration & References \\
\hline Oral squamous & $\mathrm{KB}$ & Induced apoptosis & $\begin{array}{c}\downarrow \text { cell proliferation, } \uparrow \text { TUNEL }+ \text { cells in KB } \\
\text { cells, } \uparrow \text { caspase } 3, \uparrow \text { caspase } 9, \uparrow \text { Bax, } \downarrow \\
\text { Bcl- } 2, \downarrow \text { oxygen consumption rate, } \\
\text { Induced a significant mitochondrial } \\
\text { dysfunction, } \uparrow \text { cell number in the G } 0 / G 1 \\
\text { phase, }\end{array}$ & $\begin{array}{c}0,12.5,25,50 \text { and } \\
100 \mu \mathrm{M}\end{array}$ & [?] \\
\hline Thyroid & FTC 238 & Induces apoptosis & $\begin{array}{c}\downarrow \text { proliferation, migration and invasion } \\
\text { by tumor cells, } \downarrow \text { bcl- } 2, \uparrow \text { bax, } \downarrow \text { cyclin D1, } \\
\text { No change in CREB phosphorylation, }\end{array}$ & $\begin{array}{c}0,2.5,5,10 \text { and } \\
25 \mu \mathrm{M}\end{array}$ & [?] \\
\hline \multirow{4}{*}{ Melanoma } & Colo-829 & Induces apoptosis & $\begin{array}{c}\downarrow \text { NQO1 protein, } \uparrow \text { formation of } \\
\text { superoxide, } \uparrow \text { oxidative stress, } \uparrow \text { TP53 } \uparrow \\
\text { CDKN1A genes, } \downarrow \text { p53 protein }\end{array}$ & 0.1 to $100 \mu \mathrm{g} / \mathrm{mL}$ & [?] \\
\hline & C-32 & Induces apoptosis & $\begin{array}{l}\downarrow \text { transcription of the gene encoding the } \\
\text { histone H3, } \downarrow \text { NQO1 protein, } \uparrow \text { formation } \\
\text { of superoxide, } \uparrow \text { oxidative stress, } \uparrow \text { TP53 } \\
\uparrow \text { CDKN1A genes, } \uparrow \text { BAX gene, } \downarrow \text { BCL-2 } \\
\text { gene, } \uparrow \text { BAX/BCL- } 2 \text { ratio, } \downarrow \text { p53 protein }\end{array}$ & 0.1 to $100 \mu \mathrm{g} / \mathrm{mL}$ & [?] \\
\hline & $\mathrm{Me}-45$ & Induces apoptosis & $\begin{array}{c}\uparrow \text { apoptotic nuclei, } \uparrow \text { cytotoxicity towards } \\
\text { malignant cells, } \uparrow \text { apoptosis arte, } \uparrow \\
\text { pro-apoptotic effects, } \uparrow \text { PARP- } 1, \downarrow \\
\text { expression of caspase-3 }\end{array}$ & $0.75-100 \mu \mathrm{M}$ & [?] \\
\hline & $\mathrm{B} 164 \mathrm{~A} 5$ and B16F10 & Induced apoptosis & $\begin{array}{c}\downarrow \text { mitochondrial oxidoreductase, } \downarrow \text { cell } \\
\text { division rate, } \uparrow \text { Bax, } \downarrow \text { Bcl- } 2, \uparrow \text { IL- }-12 \text { p70 } \\
\text { secretion, } \uparrow \text { cleaved caspase } 3, \uparrow \text { cleaved } \\
\text { PARP }\end{array}$ & $\begin{array}{c}0,40,80,120 \text { and } \\
160 \mu \mathrm{M}\end{array}$ & [?] \\
\hline $\begin{array}{l}\text { Epidermoid } \\
\text { squamous }\end{array}$ & A431 & Induces apoptosis & $\begin{array}{c}\uparrow \text { apoptotic cells, } \uparrow \text { Increased cytotoxicity } \\
\text { for cancerous cells, } \uparrow \text { PARP- } 1, \downarrow \text { amounts } \\
\text { of caspase- } 3\end{array}$ & $0.75-100 \mu \mathrm{M}$ & [?] \\
\hline \multirow{7}{*}{ Breast } & MDA-MB-231 & Anti-angiogenic & $\begin{array}{c}\uparrow \text { betulin uptake, } \downarrow \text { cell viability of the } \\
\text { cancer cells, } \uparrow \text { in vitro cytotoxicity, } \uparrow \\
\text { mononucleated cells, } \downarrow \text { in binucleated } \\
\text { cells }\end{array}$ & $\begin{array}{l}\text { Nanosuspension } \\
\text { of betulin } \\
\text { equivalent to } 5, \\
10,25,50,100 \\
150 \text { and } 200 \mu \mathrm{M}\end{array}$ & [?] \\
\hline & MDA-MB-231 & Induces apoptosis & $\begin{array}{c}\downarrow \text { cell size, } \uparrow \text { shrinkage of the cytoplasm, } \\
\downarrow \text { NF-kB p65 and p50, } \downarrow \text { IKK } \alpha \text { and } \beta, \downarrow \\
\text { ICAM- } 1, \downarrow \text { bcl-2 expressions, significantly } \\
\text { induced loss of mitochondrial } \\
\text { transmembrane potential }\end{array}$ & $0-50 \mu \mathrm{M}$ & [?] \\
\hline & $\begin{array}{l}\text { MCF-7 and } \\
\text { MDA-MB-231 }\end{array}$ & Induces apoptosis & $\begin{array}{c}\downarrow \text { histone } \mathrm{H} 3, \downarrow \text { NQO1 protein, } \uparrow \\
\text { formation of superoxide, } \uparrow \text { oxidative } \\
\text { stress, } \uparrow \text { TP53 } \uparrow \text { CDKN1A genes, } \uparrow \text { BAX } \\
\text { gene, } \downarrow \text { BCL-2 gene, } \uparrow \text { BAX } / \text { BCL-2 ratio, } \\
\downarrow \text { p53 protein }\end{array}$ & 0.1 to $100 \mu \mathrm{g} / \mathrm{mL}$ & [?] \\
\hline & $\begin{array}{l}\text { MDA-MB-231 and } \\
\text { BT-549 }\end{array}$ & Inhibited metastasis & $\begin{array}{c}\downarrow \text { aerobicglycolysis, } \downarrow \text { reduction of lactate } \\
\text { production, } \downarrow \text { down regulation of aerobic } \\
\text { glycolysis-related proteins, } \uparrow \text { GRP78 } \\
\text { overexpression, } \downarrow \text { c-Myc-mediated } \\
\text { glycolysis, } \downarrow \text { MMP-2 and MMP-9, } \uparrow \\
\text { LDHB, } \uparrow \text { PERK signaling, } \uparrow \\
\text { phosphorylation of elF } 2 \alpha\end{array}$ & $\begin{array}{c}0,2.5,5,10,15 \\
20,25,30,40 \text { and } \\
50 \mu \mathrm{M}\end{array}$ & [?] \\
\hline & $\begin{array}{l}\text { MCF-7, and } \\
\text { MDA-MB-231 }\end{array}$ & Induces apoptosis & $\begin{array}{l}\downarrow \text { cancer cell proliferation and augments } \\
\text { chemosensitivity of taxol, } \uparrow \text { cleaved } \\
\text { PARP, } \uparrow \text { Cytochrome c, } \uparrow \text { Bax, } \downarrow \text { Bcl- } 2, \uparrow \\
\text { intracellular free calcium concentration }\end{array}$ & $\begin{array}{l}\text { BA - 0.1-50 } \\
\mu \mathrm{MTaxol} 0-24 \\
\mathrm{nM}\end{array}$ & [?] \\
\hline & MCF7 & Induces apoptosis & $\begin{array}{l}\downarrow \text { cancer cell growth, } \uparrow \text { DNA } \\
\text { fragmentation, }\end{array}$ & $\begin{array}{l}\text { IC50 values of } \\
8.32\end{array}$ & [?] \\
\hline & MCF-7 & Induces apoptosis & $\begin{array}{c}\uparrow \text { caspase- } 9 \text { activity, } \uparrow \text { caspase- } 3, \uparrow \text { Bax }, \uparrow \\
\text { Bak }\end{array}$ & $\begin{array}{l}0,1,5,10,20,50 \\
\text { and } 100 \mu \mathrm{g} / \mu \mathrm{l}\end{array}$ & [? ] \\
\hline
\end{tabular}


Table 1. Cont.

\begin{tabular}{|c|c|c|c|c|c|}
\hline Type of Cancer & Cell Lines & Effects & Mechanisms & Concentration & References \\
\hline Ductal & T47D & Induces apoptosis & $\begin{array}{c}\downarrow \text { NQO1 protein, } \uparrow \text { formation of } \\
\text { superoxide, } \uparrow \text { oxidative stress, } \uparrow \text { TP53 } \uparrow \\
\text { CDKN1A genes, }\end{array}$ & 0.1 to $100 \mu \mathrm{g} / \mathrm{mL}$ & {$[?]$} \\
\hline \multirow{7}{*}{ Lung } & $\begin{array}{l}\text { A549, HepG2and } \\
\text { 5RP7 }\end{array}$ & Induces apoptosis & $\begin{array}{c}\uparrow \text { rate of Apoptosis, caused G1 cell cycle } \\
\text { arrest, } \uparrow \text { cleaved caspase } 3\end{array}$ & $\begin{array}{l}\mathrm{IC}_{50} \text { values of } \\
207.7,125.0 \text { and } \\
28.3 \mu \mathrm{g} / \mathrm{mL}\end{array}$ & {$[?]$} \\
\hline & $\begin{array}{l}\text { HKULC2, H1299, } \\
\text { and H23 }\end{array}$ & $\begin{array}{l}\text { Inhibit metastatic } \\
\text { ability }\end{array}$ & $\begin{array}{c}\uparrow \text { cycle arrest in G1 phase, } \downarrow \text { migration } \\
\text { and invasive potential of cells, } \uparrow \text { p21, } \uparrow \\
\text { p53, } \downarrow \text { CD133, } \downarrow \text { ALDH, } \downarrow \text { BCL2, } \downarrow \text { MCL1, } \\
\downarrow \text { c-Myc expression, } \downarrow \text { ABCG1 protein }\end{array}$ & $\begin{array}{l}10 \mu \mathrm{M} \text { of } \\
\text { betulinic acid } \\
\text { nanoparticles }\end{array}$ & {$[?]$} \\
\hline & A549 & Induces apoptosis & $\begin{array}{c}\downarrow \text { histone } \mathrm{H} 3, \downarrow \text { NQO1 protein, } \uparrow \\
\text { formation of superoxide, } \uparrow \text { oxidative } \\
\text { stress, } \uparrow \text { TP53 } \uparrow \text { CDKN1A genes, } \downarrow \text { p53, } \uparrow \\
\text { BAX/BCL-2 ratio }\end{array}$ & 0.1 to $100 \mu \mathrm{g} / \mathrm{mL}$ & {$[?]$} \\
\hline & NCI-H460 & $\begin{array}{l}\text { Antimetastatic and } \\
\text { Apoptosis }\end{array}$ & $\begin{array}{c}\uparrow \text { caspase-3, } 6 \text { and 9), } \uparrow \text { BAX, } \uparrow \text { BAK, } \downarrow \\
\text { BCL-2, } \downarrow \text { p53, } \downarrow \text { MMP-2/-9. } \downarrow \\
\text { Osteopontin }\end{array}$ & $\begin{array}{c}10,25,50,75, \text { and } \\
100 \mu \mathrm{M}\end{array}$ & {$[?]$} \\
\hline & A549 & Induces apoptosis & $\begin{array}{c}\text { T caspase-9 activity, } \uparrow \text { caspase- } 3, \uparrow \text { Bax, } \uparrow \\
\text { Bak }\end{array}$ & $\begin{array}{l}0,1,5,10,20,50 \\
\text { and } 100 \mu g / \mu \mathrm{L}\end{array}$ & {$[?]$} \\
\hline & A549 & Induced apoptosis & $\begin{array}{l}\downarrow \text { PCBP } 1, \downarrow \text { isoform } 1 \text { of } 3-\mathrm{HAD} \text { CoA } \\
\text { dehydrogenase, } \downarrow \text { HSP } 90-\alpha 2, \downarrow \text { ECH }\end{array}$ & $\begin{array}{c}0,12.5,25,50 \text { and } \\
100 \mu \mathrm{M}\end{array}$ & [?] \\
\hline & A549 & Induces apoptosis & $\begin{array}{c}\downarrow \text { proliferation, migration and invasion } \\
\text { by tumor cells, } \downarrow \text { bcl- } 2, \uparrow \text { bax, } \downarrow \text { cyclin D1, } \\
\text { No change in CREB phosphorylation, }\end{array}$ & $\begin{array}{c}0,2.5,5,10 \text { and } \\
25 \mu \mathrm{M}\end{array}$ & {$[?]$} \\
\hline \multirow{3}{*}{ Gastric } & $\begin{array}{l}\text { SNU-16 and } \\
\text { NCI-N87 }\end{array}$ & Triggers apoptosis & $\begin{array}{c}\uparrow \text { cytotoxic and inhibitory effects on } \\
\text { cancer cells, } \downarrow \text { migratory and invasive } \\
\text { abilities of cancer cells, } \downarrow \text { EMT } \\
\text { progression, } \downarrow \text { N-cadherin, } \uparrow \text { E-cadherin }\end{array}$ & $\begin{array}{l}0,2.5,5,10,20,40 \\
\text { and } 80 \mu \mathrm{M}\end{array}$ & {$[?]$} \\
\hline & $\begin{array}{l}\text { BGC-823, MNK45 } \\
\text { and } 293 \mathrm{~T}\end{array}$ & Induces apoptosis & $\begin{array}{c}\downarrow \text { proliferation and migration the cancer } \\
\text { cells, } \downarrow \text { expression of VASP mRNA, } \downarrow \\
\text { Cyclin D1, } \downarrow \text { PCNA, } \downarrow \text { c-Myc, } \downarrow \text { AKT, } \downarrow \\
\text { Vimentin, } \downarrow \text { NF-kB activity, } \downarrow \text { p-p65 } \\
\text { protein }\end{array}$ & $0-60 \mu \mathrm{M}$ & {$[?]$} \\
\hline & SGC7901 & Induced apoptosis & $\begin{array}{c}\downarrow \text { cell proliferation, } \uparrow \text { Caspase- } 3 \text { and } 9 \\
\text { activities, caspase- } 8 \text { activity remained } \\
\text { unchanged, } \uparrow \text { PARP cleavage, } \uparrow \text { Bax, } \uparrow \\
\text { Bak, } \downarrow \text { Bcl- } 2, \downarrow \text { XIAP, } \uparrow \text { intracellular ROS } \\
\text { level, }\end{array}$ & $\begin{array}{l}0,1,5,10,20,50 \\
\quad 100 \mu \mathrm{g} / \mu \mathrm{L}\end{array}$ & [?] \\
\hline Bladder & $\begin{array}{l}\text { T-24, UMUC-3, and } \\
5637\end{array}$ & Induced apoptosis & $\begin{array}{c}\downarrow \text { cell proliferation and migration } \\
\text { potential of cells, } \downarrow \text { Cdc } 25 \text { c, loss of } \\
\text { mitochondrial membrane potential, } \uparrow \\
\text { Bax, } \uparrow \text { cleaved- PARP, } \uparrow \text { caspase- } 3,8 \text {, and } \\
9, \downarrow \text { wound healing and invasion ability, } \\
\downarrow \text { Snail, } \downarrow \text { Slug, } \downarrow \text { MMP-9 }\end{array}$ & $\begin{array}{l}0,10,15,20 \text { and } \\
30 \mu g / \mu \mathrm{L}\end{array}$ & {$[?]$} \\
\hline \multirow{3}{*}{ Colon } & HCT116 and HT29 & Induced apoptosis & $\begin{array}{c}\downarrow \text { viability of HCT116 cells, } \uparrow \text { number of } \\
\text { floating cells, } \uparrow \text { rounding of cells, } \uparrow \\
\text { emergence of irregular bulges in cell } \\
\text { membrane, } \uparrow \text { condensed chromatin, } \uparrow \\
\text { micronucleation, }\end{array}$ & $\begin{array}{l}0,1,5,10,20,50 \\
\text { and } 100 \mu \mathrm{g} / \mu \mathrm{L}\end{array}$ & {$[?]$} \\
\hline & НТ-29 & Induces apoptosis & $\begin{array}{c}\downarrow \text { proliferation, migration and invasion } \\
\text { by tumor cells, } \downarrow \text { Bcl- } 2, \uparrow \text { Bax, } \downarrow \text { cyclin D1, } \\
\text { No change in CREB phosphorylation, } \\
\text { Amounts of the CREB protein, and } \\
\text { ERK } 1 / 2, \text { Akt, CaMKII kinases remained } \\
\text { unchanged }\end{array}$ & $\begin{array}{c}0,2.5,5,10 \text { and } \\
25 \mu \mathrm{M}\end{array}$ & {$[?]$} \\
\hline & $\begin{array}{l}\text { HCT116, SW480 and } \\
\text { DLD-1 }\end{array}$ & $\begin{array}{l}\text { Promoted apoptosis } \\
\text { and inhibited } \\
\text { metastasis }\end{array}$ & $\begin{array}{c}\uparrow \text { Bax, } \uparrow \text { caspase-3, } \downarrow \text { Bcl- } 2, \uparrow \text { ROS, } \downarrow \\
\text { mitochondrial membrane potential, } \downarrow \\
\text { migration and invasion of colorectal } \\
\text { cancer cells, } \downarrow \text { MMPs, } \uparrow \text { MMPs inhibitor } \\
\text { (TIMP-2) }\end{array}$ & $\begin{array}{c}0,05,10,20,40 \\
\text { and } 80 \mu \mathrm{M}\end{array}$ & {$[?]$} \\
\hline
\end{tabular}


Table 1. Cont

\begin{tabular}{|c|c|c|c|c|c|}
\hline Type of Cancer & Cell Lines & Effects & Mechanisms & Concentration & References \\
\hline Pancreatic & $\begin{array}{l}\text { Mia PaCa-2 and } \\
\text { Panc-1 }\end{array}$ & Inhibits stemness & $\begin{array}{c}\downarrow \text { proliferation and tumorsphere } \\
\text { formation, } \downarrow \text { EMT, activates AMPK } \\
\text { signaling } \downarrow \text { mRNA expression levels of } \\
\text { Sox2, Oct4, } \downarrow \text { Nanog and Nanog, } \uparrow \\
\text { E-cadherin, } \downarrow \text { vimentin, } \downarrow \text { effects of } \\
\text { gemcitabine on stemness, } \uparrow \text { sensitivity of } \\
\text { pancreatic cancer cells to gemcitabine }\end{array}$ & $\begin{array}{l}0,12.5,25,50,100 \\
\text { and } 200 \mu \mathrm{M}\end{array}$ & [?] \\
\hline \multirow[t]{2}{*}{ Hepatocellular } & $\begin{array}{l}\text { HepG2, LM3, and } \\
\text { MHCC97H }\end{array}$ & Induces apoptosis & $\begin{array}{c}\downarrow \text { cell viability and proliferation, } \downarrow \\
\text { migration and invasion, } \downarrow \text { adhesive } \\
\text { ratios, } \uparrow \text { condensed nuclei and nuclear } \\
\text { fragmentation, } \uparrow \text { apoptosis rate } \\
\text { significantly, } \uparrow \text { Bax, } \uparrow \text { cleaved caspase- } 3, \downarrow \\
\text { Bcl- } 2, \downarrow \text { ROS level, lost mitochondrial } \\
\text { membrane potential, } \downarrow \text { MMP-2 and } \\
\text { MMP-9, } \uparrow \text { TIMP2 }\end{array}$ & $2.5-40 \mu \mathrm{M}$ & [?] \\
\hline & HepG2 & Induces apoptosis & $\begin{array}{c}\uparrow \text { caspase-9 activity, } \uparrow \text { caspase- } 3, \uparrow \text { Bax, } \uparrow \\
\text { Bak }\end{array}$ & $\begin{array}{l}0,1,5,10,20,50 \\
\text { and } 100 \mu \mathrm{g} / \mu \mathrm{L}\end{array}$ & [?] \\
\hline \multirow{3}{*}{ Renal } & 786-O and ACHN & Induces apoptosis & $\begin{array}{c}\downarrow \text { migrative and invasive capabilities of } \\
\text { cancer cells, } \downarrow \text { Bcl } 2, \downarrow \text { Bcl- } 2, \uparrow \text { Bax, } \uparrow \\
\text { cleaved caspase- } 3, \downarrow \text { B-cell lymphoma } 2, \\
\uparrow \text { ROS, } \uparrow \text { loss of mitochondrial } \\
\text { membrane potential, } \downarrow \text { MMP- } 2, \downarrow \text { MMP9, } \\
\downarrow \text { Vimentin, } \uparrow \text { tissue inhibitor of } \\
\text { metalloproteinase } 2, \uparrow \text { E-cadherin }\end{array}$ & $\begin{array}{c}0,5,10 \text { and } 20 \\
\mu \mathrm{g} / \mathrm{mL}\end{array}$ & [?] \\
\hline & 786-O and Caki-2 & mTor activation & $\begin{array}{l}\downarrow \text { colonies of cancer cells, } \downarrow \text { glucose } \\
\text { consumption, } \downarrow \text { lactate production, } \downarrow \\
\text { p-S6, p-4EBP1, } \downarrow \text { aerobic glycolysis }\end{array}$ & $0,0.5,1$ and $5 \mu \mathrm{M}$ & [?] \\
\hline & $\mathrm{RCC} 4$ & Induces apoptosis & $\begin{array}{c}\downarrow \text { cell viability, } \uparrow \text { caspase- } 3,7,8 \text { and 9, } \uparrow \\
\text { TRAIL R1/DR4 and R2/DR5, } \uparrow \text { TNFR1, } \uparrow \\
\text { cytotoxicity, } \uparrow \text { cleaved PARP, } \downarrow \text { protein } 1 \\
\text { (MDR1), } \uparrow \mathrm{t}-\mathrm{Bid}, \uparrow \text { Bax, } \uparrow \text { PuMA, } \downarrow \text { Bcl-2, } \\
\downarrow \text { XIAP }\end{array}$ & $\begin{array}{l}0,6.25,12.5,25 \\
\quad \text { and } 50 \mu \mathrm{M}\end{array}$ & [?] \\
\hline Neuroblastoma & SK-N-AS & Induces apoptosis & $\begin{array}{l}\downarrow \text { proliferation, migration and invasion } \\
\text { by tumor cells, } \downarrow \text { bcl- } 2, \uparrow \text { bax, } \downarrow \text { cyclin D1, } \\
\text { No change in CREB phosphorylation, }\end{array}$ & $\begin{array}{c}0,2.5,5,10 \text { and } \\
25 \mu \mathrm{M}\end{array}$ & [?] \\
\hline Prostate & LNCaP and PC-3 & Induced apoptosis & $\begin{array}{c}\downarrow \text { STAT3 (Y727), } \downarrow \text { c-Jun (S63), } \downarrow \text { eNOS } \\
\text { (S1177) }, \downarrow \text { ap70 S6 kinase (T389), } \downarrow \text { p53 } \\
\text { (S392) } \downarrow \text { PYK2 (Y402) }\end{array}$ & $1-90 \mu \mathrm{M}$ & [?] \\
\hline \multirow[t]{2}{*}{ Ovarian } & SKOV3 and SW626 & Inhibited metastasis & $\begin{array}{l}\downarrow \text { proliferation, } \downarrow \text { N-cadherin, } \uparrow \\
\text { E-cadherin, } \downarrow \text { EMT process }\end{array}$ & $\begin{array}{l}0,2.5,5,10,20 \\
40, \text { and } 80 \mu \mathrm{M}\end{array}$ & [?] \\
\hline & A2780 & Induces apoptosis & $\begin{array}{c}\downarrow \text { viability of cancer cells, } \uparrow \text { condensation } \\
\text { of nuclei, } \uparrow \text { caspase- } 8,3,9, \uparrow \text { Bax, }\end{array}$ & 25 and $50 \mu \mathrm{M}$ & [?] \\
\hline \multirow[t]{2}{*}{ Cervix } & HeLa & $\begin{array}{l}\text { Suppresses } \\
\text { angiogenesis }\end{array}$ & $\begin{array}{c}\downarrow \text { hypoxia-induced accumulation of } \\
\text { HIF- } 1 \alpha, \downarrow \text { VEGF, } \downarrow \text { GLUT1, PDK } 1, \uparrow \beta 1, \beta \\
2 \text {, and } \beta 5 \text { activities of the proteasome }\end{array}$ & $3-30 \mu \mathrm{M}$ & [?] \\
\hline & HeLa & Induces apoptosis & $\begin{array}{c}\downarrow \text { cancer cell growth, } \uparrow \text { nuclear } \\
\text { condensation and fragmentation, }\end{array}$ & $\begin{array}{l}\mathrm{IC}_{50} \text { values of } \\
6.67\end{array}$ & [?] \\
\hline $\begin{array}{l}\text { Equine } \\
\text { malignant } \\
\text { melanoma }\end{array}$ & $\begin{array}{l}\text { PriFi1, PriFi2, } \\
\text { MelDuWi and } \\
\text { eRGO1 }\end{array}$ & Induces apoptosis & $\begin{array}{l}\downarrow \text { cell proliferation, } \downarrow \text { cell viability, } \uparrow \text { cell } \\
\text { cycle arrest }\end{array}$ & - & [?] \\
\hline $\begin{array}{c}\text { Canine } \\
\text { osteosarcoma }\end{array}$ & D-17 & Induces apoptosis & $\begin{array}{c}\downarrow \text { Growth of cancer cells. arrested cell } \\
\text { cycle in S phase, } \uparrow \% \text { age of apoptotic cells }\end{array}$ & $\begin{array}{c}1,5,10,15,20,25 \\
30 \text { and } 40 \mu \mathrm{M}\end{array}$ & [?] \\
\hline
\end{tabular}


Table 2. Anticancer effects of betulin and betulinic acid based on in vivo studies.

\begin{tabular}{|c|c|c|c|c|c|c|}
\hline Type of Cancer & Animal Models & Effects & Mechanisms & Dosage & Duration & References \\
\hline Oral squamous & $\begin{array}{c}\text { Balb/c nude mice } \\
\text { injected with KB cells } \\
\left(1 \times 10^{7} \text { cells per mouse }\right)\end{array}$ & $\begin{array}{l}\text { Inhibited the } \\
\text { increase in tumor } \\
\text { volume }\end{array}$ & $\begin{array}{c}\downarrow \text { p53 in implanted } \\
\text { tumor, } \downarrow \text { STAT3 } \\
\text { signaling, } \downarrow \text { p- } \\
\text { STAT3 in tumor } \\
\text { tissues declined }\end{array}$ & 50,75 and $150 \mathrm{mg} / \mathrm{kg}$ & 21 days & [?] \\
\hline Colorectal & $\begin{array}{c}\text { BALB } / \text { c nude mice } \\
\text { xenografted with } \\
\text { HCT116 cells } \\
\left(1 \times 10^{7} \text { cells per mouse }\right)\end{array}$ & Inhibits metastasis & $\begin{array}{c}\downarrow \mathrm{MMP}-2, \downarrow \text { Ki-67, } \uparrow \\
\text { caspase-3 }\end{array}$ & 0,10 , and $20 \mathrm{mg} / \mathrm{kg}$ & 21 days & [?] \\
\hline Gastric & $\begin{array}{l}\text { BALB } / \text { c nude mice } \\
\text { xenografted with } \\
\text { SNU-16 cells } \\
\left(1 \times 10^{7} \text { cells } / \text { mouse }\right) \\
\end{array}$ & $\begin{array}{l}\text { Delay tumour } \\
\text { growth and inhibit } \\
\text { pulmonary } \\
\text { metastasis }\end{array}$ & $\begin{array}{c}\downarrow \text { tumour weight, } \downarrow \\
\text { number of metastatic } \\
\text { nodules, } \downarrow \text { Ki-67 } \downarrow \\
\text { MMP2 }\end{array}$ & $40 \mathrm{mg} / \mathrm{kg}$ & 21 days & [?] \\
\hline Breast & $\begin{array}{l}\text { Adult orange zebra } \\
\text { danio fishes }\end{array}$ & Anti-angiogenesis & $\downarrow$ tail fin regrowth & $\begin{array}{l}\text { Betulin suspension } \\
\text { (BetS) ( } 5 \mathrm{mg} / \mathrm{g} \text { of } \\
\text { betulin) and Group III } \\
\text { - BeTNS ( } 5 \mathrm{mg} / \mathrm{g} \text { of } \\
\text { betulin) }\end{array}$ & 15 days & [?] \\
\hline Breast & $\begin{array}{c}\text { Balb/c-nu/nu mice } \\
\text { subcutaneously injecting } \\
\text { MDA-MB-231 cells } \\
\left(5 \times 10^{6}\right)\end{array}$ & $\begin{array}{l}\text { Inhibited tumor } \\
\text { growth }\end{array}$ & $\begin{array}{c}\downarrow \text { Body weight loss, } \uparrow \\
\text { apoptosis ratio, } \downarrow \\
\text { Ki67 expression, } \uparrow \\
\text { expression of GRP78, } \\
\uparrow \text { CHOP }\end{array}$ & $\begin{array}{c}\text { BA } 250 \mathrm{mg} / \mathrm{kg}+\text { taxol } \\
10 \mathrm{mg} / \mathrm{kg}\end{array}$ & 24 days & [?] \\
\hline Breast & $\begin{array}{l}\text { Balb/c nude mice } \\
\text { xenografted with } \\
\text { MDA-MB-231 cells } \\
\qquad\left(2 \times 10^{5}\right)\end{array}$ & Inhibits metastasis & $\begin{array}{c}\downarrow \text { MMP-2 \& 9, } \downarrow \\
\text { vimentin, } \uparrow \\
\text { E-cadherin, } \uparrow \text { GRP78, } \\
\downarrow \beta \text {-catenin, } \downarrow \text { c-Myc }\end{array}$ & 125 and $250 \mathrm{mg} / \mathrm{kg}$ & 28 days & [?] \\
\hline Hepatocellular & $\begin{array}{c}\text { NOD/SCID mice } \\
\text { implanted } \\
\text { subcutaneously with } 100 \\
\mu \mathrm{L} \text { HepG2 cells } \\
\text { suspensions } \\
\left(1 \times 10^{7} \text { cells } / \text { mouse }\right)\end{array}$ & $\begin{array}{l}\text { Reduces tumour } \\
\text { growth }\end{array}$ & $\begin{array}{c}\downarrow \text { Ki-67 positive cells, } \\
\downarrow \text { MMP-2 positive } \\
\text { cells, } \downarrow \text { cancer cell } \\
\text { proliferation, } \downarrow \\
\text { Extents of metastatic } \\
\text { nodules, } \downarrow \text { lung } \\
\text { weights }\end{array}$ & $10 \mathrm{mg} / \mathrm{kg}$ & 18 days & [?] \\
\hline Renal & $\begin{array}{c}\text { BALB } / \text { c nude mice } \\
\text { injected with } 786-O \text { cells } \\
\left(1 \times 10^{6} \text { cells per mouse }\right)\end{array}$ & Inhibits metastasis & $\begin{array}{c}\downarrow \text { Ki67-positive cells, } \\
\downarrow \text { MMP9-positive } \\
\text { cells, }\end{array}$ & 0,5 , and $10 \mathrm{mg} / \mathrm{kg}$ & 15 days & [?] \\
\hline Ovarian & $\begin{array}{l}\text { BALB } / \text { c nude mice } \\
\text { injected with SKOV3 } \\
\text { cells }\left(5 \times 10^{6} \text { cells }\right)\end{array}$ & $\begin{array}{l}\text { Inhibits tumor } \\
\text { growth and } \\
\text { Inhibited metastasis }\end{array}$ & $\begin{array}{l}\downarrow \text { EMT process }, \downarrow \\
\text { Ki- } 67+\text { cells, } \downarrow \\
\text { MMP- } 2+\text { cells }\end{array}$ & $40 \mathrm{mg} / \mathrm{kg}$ & 21 days & [?] \\
\hline
\end{tabular}

\section{Conclusions}

In this study, clear evidences are presented in favor of considering birch tree barkderived betulin as a potential lead molecule for further development of anticancer agent. The anti-inflammatory properties of betulin would make it possible to apply this natural compound especially for the treatment of inflammation-related tumors. However, to reach this goal, the bottlenecks associated with low bioavailability should be solved first as well as the safety issues of this triterpene need to be enlightened. In this way, it is expected that betulin will represent "a long-known but newly discovered" phytochemical for the use in oncological field. The necessity for new anticancer drugs is obvious in view of several impediments related to the current treatment modalities, including acquired drug resistance and toxicities towards normal tissues. Therefore, identification and characterization of novel anticancer agents from naturally occurring products may lead to development of more efficient and safer cancer therapies in future, especially considering the steadily rising incidence rates of new cancer cases all over the world. In addition, chemical derivatizations or structural modifications of existing natural agents may also open new avenues in medicinal chemistry. 
Author Contributions: H.S.T.: Draft preparation, literature search and writing; K.S.: Draft preparation and introduction Section, D.S.G. and G.K.: Contributed in absorption, metabolism and nanodelivery sections: D.A.: Contributed in tables; N.C.P.: Contributed in Co effects section; R.C.: Contributed in COX section; M.B.Y.: Contributed in Nrf 2 section; J.K.: Contributed in NF-kB section, M.K.: Contributed in chemistry section; V.K.G.: Contributed in nano-delivery and references section; G.S.: Final editing and proof reading. All authors have read and agreed to the published version of the manuscript.

Funding: This research received no external funding.

Institutional Review Board Statement: Not applicable.

Informed Consent Statement: Not applicable.

Data Availability Statement: Not applicable.

Conflicts of Interest: The authors declare no conflict of interest.

\begin{abstract}
Abbreviations
hUGT1A3: UDP-glucuronosyltransferase 1A3 (human),hSULT2A1: human dehydroepiandrosterone sulfotransferase, ADME: Absorption Distribution Metabolism Excretion, TPSA: Total prostate-specific antigen, NF-kB: Nuclear factor kappa B, Bcl-2: B-cell lymphoma 2, XIAP: X-linked inhibitor of apoptosis protein, Bak: BCL-2 antagonist/killer, Bax: BCL-2-associated X, IKK $\alpha$ : IKB kinase, ICAM-1: Intercellular adhesion molecule-1, COX: Cyclooxygenase, TNF- $\alpha$ : Tumor necrosis factor $\alpha$, NADPH: Nicotinamide-adenine dinucleotide phosphate, Keap1: Kelch-like ECH-associated protein 1), ARNT: Aryl Hydrocarbon Receptor Nuclear Translocator, AhR: Aryl hydrocarbon receptor, CYP1A1: Cytochrome P450 Family 1 Subfamily A Member 1, JNK: c-Jun N-terminal kinases, ERK: extracellular signal-regulated kinase, Fas:FS-7-associated surface antigen, VEGF: Vascular endothelial growth factor, IL: Interleukin, IFN- $\gamma$ : Interferon gamma, iNOS: Inducible nitric oxide synthase, CXCR4:C-X-C chemokine receptor type 4, TRAIL: TNF-related apoptosisinducing ligand.
\end{abstract}

\title{
References
}

1. Gullo, V.P.; McAlpine, J.; Lam, K.S.; Baker, D.; Petersen, F. Drug discovery from natural products. J. Ind. Microbiol. Biotechnol. 2006, 33, 523-531. [CrossRef] [PubMed]

2. Mishra, S.; Verma, S.S.; Rai, V.; Awasthee, N.; Chava, S.; Hui, K.M.; Kumar, A.P.; Challagundla, K.B.; Sethi, G.; Gupta, S.C. Long non-coding RNAs are emerging targets of phytochemicals for cancer and other chronic diseases. Cell. Mol. Life Sci. 2019, 76, 1947-1966. [CrossRef]

3. Tewari, D.; Nabavi, S.F.; Nabavi, S.M.; Sureda, A.; Farooqi, A.A.; Atanasov, A.G.; Vacca, R.A.; Sethi, G.; Bishayee, A. Targeting activator protein 1 signaling pathway by bioactive natural agents: Possible therapeutic strategy for cancer prevention and intervention. Pharmacol. Res. 2018, 128, 366-375. [CrossRef] [PubMed]

4. Patel, S.M.; Nagulapalli Venkata, K.C.; Bhattacharyya, P.; Sethi, G.; Bishayee, A. Potential of neem (Azadirachta indica L.) for prevention and treatment of oncologic diseases. Semin. Cancer Biol. 2016, 40-41, 100-115. [CrossRef] [PubMed]

5. Demain, A.L.; Vaishnav, P. Natural products for cancer chemotherapy. Microb. Biotechnol. 2011, 4, 687-699. [CrossRef]

6. Sung, H.; Ferlay, J.; Siegel, R.L.; Laversanne, M.; Soerjomataram, I.; Jemal, A.; Bray, F. Global cancer statistics 2020: GLOBOCAN estimates of incidence and mortality worldwide for 36 cancers in 185 countries. CA. Cancer J. Clin. 2021, 71, 209-249. [CrossRef] [PubMed]

7. Arellano, E.; Díaz, V.; Rodríguez, J. Current status and future directions in unresectable stage III non-small cell lung cancer. J. Clin. Transl. Res. 2020, 6, 109-120. [CrossRef]

8. De Dios, N.; Murcia-Mejía, M. Current and future strategies in radiotherapy for small-cell lung cancer. J. Clin. Transl. Res. 2020, 6, 97-108. [CrossRef]

9. Kashyap, D.; Garg, V.K.; Sandberg, E.N.; Goel, N.; Bishayee, A. Oncogenic and tumor suppressive components of the cell cycle in breast cancer progression and prognosis. Pharmaceutics 2021, 13, 569. [CrossRef] [PubMed]

10. Kashyap, D.; Tuli, H.S.; Garg, V.K.; Goel, N.; Bishayee, A. Oncogenic and Tumor-Suppressive Roles of MicroRNAs with Special Reference to Apoptosis: Molecular Mechanisms and Therapeutic Potential. Mol. Diagn. Ther. 2018, 22, 179-201. [CrossRef]

11. Kashyap, D.; Garg, V.K.; Goel, N. Intrinsic and Extrinsic Pathways of Apoptosis: Role in Cancer Development and Prognosis. Adv. Protein. Chem. Struct. Biol. 2021, 125, 73-120. [PubMed] 
12. Aggarwal, V.; Kashyap, D.; Sak, K.; Tuli, H.S.; Jain, A.; Chaudhary, A.; Garg, V.K.; Sethi, G.; Yerer, M.B. Molecular mechanisms of action of tocotrienols in cancer: Recent trends and advancements. Int. J. Mol. Sci. 2019, 20, 656. [CrossRef] [PubMed]

13. Kashyap, D.; Garg, V.K.; Tuli, H.S.; Yerer, M.B.; Sak, K.; Sharma, A.K.; Kumar, M.; Aggarwal, V.; Sandhu, S.S. Fisetin and quercetin: Promising flavonoids with chemopreventive potential. Biomolecules 2019, 9, 174. [CrossRef]

14. Kashyap, D.; Tuli, H.S.; Garg, V.K.; Bhatnagar, S.; Sharma, A.K. Ursolic acid and quercetin: Promising anticancer phytochemicals with antimetastatic and antiangiogenic potential. Tumor Microenviron. 2018, 1, 9-15. [CrossRef]

15. Tuli, H.S.; Tuorkey, M.J.; Thakral, F.; Sak, K.; Kumar, M.; Sharma, A.K.; Sharma, U.; Jain, A.; Aggarwal, V.; Bishayee, A. Molecular mechanisms of action of genistein in cancer: Recent advances. Front. Pharmacol. 2019, 10, 1-16. [CrossRef]

16. Kashyap, D.; Tuli, H.S.; Sharma, A.K. Ursolic acid (UA): A metabolite with promising therapeutic potential. Life Sci. 2016, 146, 201-213. [CrossRef]

17. Kashyap, D.; Sharma, A.; Tuli, H.S.; Sak, K.; Mukherjee, T.; Bishayee, A. Molecular targets of celastrol in cancer: Recent trends and advancements. Crit. Rev. Oncol. Hematol. 2018, 128, 70-81. [CrossRef]

18. Tuli, H.S.; Yerer, M.B.; Sak, K. Editorial: Current aspects in chemopreventive strategies. Front. Pharmacol. 2021, 11, $2020-2021$. [CrossRef] [PubMed]

19. Amiri, S.; Dastghaib, S.; Ahmadi, M.; Mehrbod, P.; Khadem, F.; Behrouj, H.; Aghanoori, M.R.; Machaj, F.; Ghamsari, M.; Rosik, J.; et al. Betulin and its derivatives as novel compounds with different pharmacological effects. Biotechnol. Adv. 2020, $38,107409$. [CrossRef]

20. Fulda, S. Betulinic Acid for cancer treatment and prevention. Int. J. Mol. Sci. 2008, 9, 1096-1107. [CrossRef]

21. Blondeau, D.; St-Pierre, A.; Bourdeau, N.; Bley, J.; Lajeunesse, A.; Desgagné-Penix, I. Antimicrobial activity and chemical composition of white birch (Betula papyrifera Marshall) bark extracts. Microbiologyopen 2020, 9, e00944. [CrossRef] [PubMed]

22. Schwiebs, A.; Radeke, H.H. Immunopharmacological Activity of Betulin in Inflammation-associated Carcinogenesis. Anticancer Agents Med. Chem. 2017, 18, 645-651. [CrossRef]

23. Hordyjewska, A.; Ostapiuk, A.; Horecka, A.; Kurzepa, J. Betulin and betulinic acid: Triterpenoids derivatives with a powerful biological potential. Phytochem. Rev. 2019, 18, 929-951. [CrossRef]

24. Green, B.; Bentley, M.D.; Chung, B.Y.; Lynch, N.G.; Jensen, B.L. Isolation of betulin and rearrangement to allobetulin. A biomimetic natural product synthesis. J. Chem. Educ. 2007, 84, 1985-1987. [CrossRef]

25. Bębenek, E.; Jastrzȩbska, M.; Kadela-Tomanek, M.; Chrobak, E.; Orzechowska, B.; Zwolińska, K.; Latocha, M.; Mertas, A.; Czuba, Z.; Boryczka, S. Novel triazole hybrids of betulin: Synthesis and biological activity profile. Molecules 2017, 22, 1876. [CrossRef] [PubMed]

26. Boryczka, S.; Bebenek, E.; Wietrzyk, J.; Kempińska, K.; Jastrzebska, M.; Kusz, J.; Nowak, M. Synthesis, structure and cytotoxic activity of new acetylenic derivatives of betulin. Molecules 2013, 18, 4526-4543. [CrossRef]

27. Mullauer, F.B.; Kessler, J.H.; Medema, J.P. Betulinic acid, a natural compound with potent anticancer effects. Anticancer. Drugs 2010, 21, 215-227. [CrossRef] [PubMed]

28. Kim, D.S.H.L.; Chen, Z.; Van Nguyen, T.; Pezzuto, J.M.; Qiu, S.; Lu, Z.Z. A concise semi-synthetic approach to betulinic acid from betulin. Synth. Commun. 1997, 27, 1607-1612. [CrossRef]

29. Hu, Z.; Wang, Z.; Luo, S.; James, M.O.; Wang, Y. Phase II metabolism of betulin by rat and human UDP-glucuronosyltransferases and sulfotransferases. Chem. Biol. Interact. 2019, 302, 190-195. [CrossRef]

30. Zhang, W.; Jiang, H.; Jin, M.; Wang, Q.; Sun, Q.; Du, Y.; Cao, L.; Xu, H. UHPLC-Q-TOF-MS/MS based screening and identification of the metabolites in vivo after oral administration of betulin. Fitoterapia 2018, 127, 29-41. [CrossRef]

31. Zichri, S.B.; Kolusheva, S.; Shames, A.I.; Schneiderman, E.A.; Poggio, J.L.; Stein, D.E.; Doubijensky, E.; Levy, D.; Orynbayeva, Z.; Jelinek, R. Mitochondria membrane transformations in colon and prostate cancer and their biological implications. Biochim. Biophys. Acta Biomembr. 2021, 1863, 18347. [CrossRef]

32. Drag-Zalesińska, M.; Drag, M.; Poreba, M.; Borska, S.; Kulbacka, J.; Saczko, J. Anticancer properties of ester derivatives of betulin in human metastatic melanoma cells (Me-45). Cancer Cell Int. 2017, 17, 4. [CrossRef] [PubMed]

33. Bębenek, E.; Chrobak, E.; Marciniec, K.; Kadela-Tomanek, M.; Trynda, J.; Wietrzyk, J.; Boryczka, S. Biological activity and in silico study of 3-modified derivatives of betulin and betulinic aldehyde. Int. J. Mol. Sci. 2019, 20, 1372. [CrossRef] [PubMed]

34. Puar, Y.R.; Shanmugam, M.K.; Fan, L.; Arfuso, F.; Sethi, G.; Tergaonkar, V. Evidence for the involvement of the master transcription factor NF- $\kappa$ B in cancer initiation and progression. Biomedicines 2018, 6, 82. [CrossRef] [PubMed]

35. Kwang, S.A.; Sethi, G.; Jain, A.K.; Jaiswal, A.K.; Aggarwal, B.B. Genetic deletion of NAD(P)H:quinone oxidoreductase 1 abrogates activation of nuclear factor- $\mathrm{kB}, \mathrm{I} \mathrm{K} \mathrm{B} \alpha$ kinase, $\mathrm{c}$-Jun N-terminal kinase, Akt, p38, and p44/42 mitogen-activated protein kinases and potentiates apoptosis. J. Biol. Chem. 2006, 281, 19798-19808. [CrossRef]

36. Manu, K.A.; Shanmugam, M.K.; Ramachandran, L.; Li, F.; Siveen, K.S.; Chinnathambi, A.; Zayed, M.E.; Alharbi, S.A.; Arfuso, F.; Kumar, A.P.; et al. Isorhamnetin augments the anti-tumor effect of capeciatbine through the negative regulation of NF- $\mathrm{B}$ signaling cascade in gastric cancer. Cancer Lett. 2015, 363, 28-36. [CrossRef]

37. Shanmugam, M.K.; Ong, T.H.; Kumar, A.P.; Lun, C.K.; Ho, P.C.; Wong, P.T.H.; Hui, K.M.; Sethi, G. Ursolic acid inhibits the initiation, progression of prostate cancer and prolongs the survival of TRAMP mice by modulating pro-inflammatory pathways. PLoS ONE 2012, 7, e32476. [CrossRef] 
38. Manu, K.A.; Shanmugam, M.K.; Li, F.; Chen, L.; Siveen, K.S.; Ahn, K.S.; Kumar, A.P.; Sethi, G. Simvastatin sensitizes human gastric cancer xenograft in nude mice to capecitabine by suppressing nuclear factor-kappa B-regulated gene products. J. Mol. Med. 2014, 92, 267-276. [CrossRef]

39. Li, F.; Shanmugam, M.K.; Chen, L.; Chatterjee, S.; Basha, J.; Kumar, A.P.; Kundu, T.K.; Sethi, G. Garcinol, a polyisoprenylated benzophenone modulates multiple proinfl ammatory signaling cascades leading to the suppression of growth and survival of head and neck carcinoma. Cancer Prev. Res. 2013, 6, 843-854. [CrossRef]

40. Matilla, J.; Zabaleta, M.; Martínez-Téllez, E.; Abal, J.; Rodríguez-Fuster, A.; Hernández-Hernández, J. New TNM staging in lung cancer (8th edition) and future perspectives. J. Clin. Transl. Res. 2020, 6, 145-154. [CrossRef]

41. Maqueda, L.; Falcón, R.; Tsai, C.; García-Pérez, A.; Minasyan, A.; Gonzalez-Rivas, D. Current role of Uniportal Video Assisted Thoracic Surgery for lung cancer treatment. J. Clin. Transl. Res. 2020, 6, 135-144. [CrossRef]

42. Hordyjewska, A.; Ostapiuk, A.; Horecka, A. Betulin and betulinic acid in cancer research. J. Pre-Clin. Clin. Res. 2018, 12, 72-75. [CrossRef]

43. Mastron, J.K.; Siveen, K.S.; Sethi, G.; Bishayee, A. Silymarin and hepatocellular carcinoma: A systematic, comprehensive, and critical review. Anticancer Drugs 2014, 26, 475-486. [CrossRef]

44. Liu, C.; Ho, P.C.L.; Wong, F.C.; Sethi, G.; Wang, L.Z.; Goh, B.C. Garcinol: Current status of its anti-oxidative, anti-inflammatory and anti-cancer effects. Cancer Lett. 2015, 362, 8-14. [CrossRef] [PubMed]

45. Lee, J.H.; Kim, C.; Kim, S.H.; Sethi, G.; Ahn, K.S. Farnesol inhibits tumor growth and enhances the anticancer effects of bortezomib in multiple myeloma xenograft mouse model through the modulation of STAT3 signaling pathway. Cancer Lett. 2015, 360, 280-293. [CrossRef]

46. Rzeski, W.; Stepulak, A.; Szymański, M.; Sifringer, M.; Kaczor, J.; Wejksza, K.; Zdzisińska, B.; Kandefer-Szerszeń, M. Betulinic acid decreases expression of bcl-2 and cyclin D1, inhibits proliferation, migration and induces apoptosis in cancer cells. Naunyn. Schmiedebergs. Arch. Pharmacol. 2006, 374, 11-20. [CrossRef]

47. Zhao, J.; Li, R.; Pawlak, A.; Henklewska, M.; Sysak, A.; Wen, L.; Yi, J.E.; Obmińska-Mrukowicz, B. Antitumor activity of betulinic acid and betulin in canine cancer cell lines. In Vivo 2018, 32, 1081-1088. [CrossRef]

48. Rzeski, W.; Stepulak, A.; Szymański, M.; Juszczak, M.; Grabarska, A.; Sifringer, M.; Kaczor, J.; Kandefer-Szerszeń, M. Betulin Elicits Anti-Cancer Effects in Tumour Primary Cultures and Cell Lines in Vitro. Basic Clin. Pharmacol. Toxicol. 2009, 105, 425-432. [CrossRef] [PubMed]

49. PA, K. Birch bark research and development. Nat. Prod. Rep. 2006, 23, 919-942. [CrossRef]

50. Tang, J.J.; Li, J.G.; Qi, W.; Qiu, W.W.; Li, P.S.; Li, B.L.; Song, B.L. Inhibition of SREBP by a small molecule, betulin, improves hyperlipidemia and insulin resistance and reduces atherosclerotic plaques. Cell Metab. 2011, 13, 44-56. [CrossRef]

51. Hengartner, M.O. The biochemistry of apoptosis. Nature 2000, 407, 770-776. [CrossRef] [PubMed]

52. Van Loo, G.; Saelens, X.; Van Gurp, M.; MacFarlane, M.; Martin, S.J.; Vandenabeele, P. The role of mitochondrial factors in apoptosis: A Russian roulette with more than one bullet. Cell Death Differ. 2002, 9, 1031-1042. [CrossRef]

53. Ahn, K.S.; Sethi, G.; Aggarwal, B.B. Reversal of chemoresistance and enhancement of apoptosis by statins through downregulation of the NF-kB pathway. Biochem. Pharmacol. 2008, 75, 907-913. [CrossRef]

54. Dai, X.; Wang, L.; Deivasigamni, A.; Looi, C.Y.; Karthikeyan, C.; Trivedi, P.; Chinnathambi, A.; Alharbi, S.A.; Arfuso, F.; Dharmarajan, A.; et al. A novel benzimidazole derivative, MBIC inhibits tumor growth and promotes apoptosis via activation of ROS-dependent JNK signaling pathway in hepatocellular carcinoma. Oncotarget 2017, 8, 12831-12842. [CrossRef] [PubMed]

55. Yang, L.; Kan, H.; Yinghui, H.; Daxin, Z.; Chang, G.; Lin, C.; Ying Hua, J. Betulin induces mitochondrial cytochrome c release associated apoptosis in human cancer cells. Mol. Carcinog. 2010, 49, 630-640. [CrossRef]

56. Li, Y.; Liu, X.; Jiang, D.; Lin, Y.; Wang, Y.; Li, Q.; Liu, L.; Jin, Y.H. Betulin induces reactive oxygen species-dependent apoptosis in human gastric cancer SGC7901 cells. Arch. Pharm. Res. 2016, 39, 1257-1265. [CrossRef]

57. Takada, Y.; Aggarwal, B.B. Betulinic Acid Suppresses Carcinogen-Induced NF-кB Activation Through Inhibition of IкB $\alpha$ Kinase and p65 Phosphorylation: Abrogation of Cyclooxygenase-2 and Matrix Metalloprotease-9. J. Immunol. 2003, 171, 3278-3286. [CrossRef]

58. Anaya-Eugenio, G.D.; Eggers, N.A.; Ren, Y.; Rivera-Chávez, J.; Douglas Kinghorn, A.; Carcache De Blanco, E.J. Apoptosis induced by (+)-Betulin through NF-kB inhibition in MDA-MB-231 breast cancer cells. Anticancer Res. 2020, 40, 6637-6647. [CrossRef] [PubMed]

59. Zeldin, D.C. Epoxygenase pathways of arachidonic acid metabolism. J. Biol. Chem. 2001, 276, 36059-36062. [CrossRef]

60. Yarla, N.S.; Bishayee, A.; Sethi, G.; Reddanna, P.; Kalle, A.M.; Dhananjaya, B.L.; Dowluru, K.S.V.G.K.; Chintala, R.; Duddukuri, G.R. Targeting arachidonic acid pathway by natural products for cancer prevention and therapy. Semin. Cancer Biol. 2016, 40-41, 48-81. [CrossRef] [PubMed]

61. Santos, C.M.M.; Ribeiro, D.; Silva, A.M.S.; Fernandes, E. 2,3-Diarylxanthones as potential inhibitors of arachidonic acid metabolic pathways. Inflammation 2017, 40, 956-964. [CrossRef] [PubMed]

62. Sugimoto, Y.; Inazumi, T.; Tsuchiya, S. Roles of prostaglandin receptors in female reproduction. J. Biochem. 2015, 157, 73-80. [CrossRef]

63. Shih, R.H.; Wang, C.Y.; Yang, C.M. NF-kappaB signaling pathways in neurological inflammation: A mini review. Front. Mol. Neurosci. 2015, 8, 77. [CrossRef] [PubMed] 
64. Aid, S.; Langenbach, R.; Bosetti, F. Neuroinflammatory response to lipopolysaccharide is exacerbated in mice genetically deficient in cyclooxygenase-2. J. Neuroinflamm. 2008, 5, 17. [CrossRef]

65. Morita, I. Distinct functions of COX-1 and COX-2. Prostaglandins Other Lipid Mediat. 2002, 68-69, 165-175. [CrossRef]

66. Kurumbail, R.G.; Kiefer, J.R.; Marnett, L.J. Cyclooxygenase enzymes: Catalysis and inhibition. Curr. Opin. Struct. Biol. 2001, 11, 752-760. [CrossRef]

67. Langenbach, R.; Loftin, C.; Lee, C.; Tiano, H. Cyclooxygenase knockout mice Models for elucidating isoform-specific functions. Biochem. Pharmacol. 1999, 58, 1237-1246. [CrossRef]

68. Vadlamudi, R.; Mandal, M.; Adam, L.; Steinbach, G.; Mendelsohn, J.; Kumar, R. Regulation of cyclooxygenase-2 pathway by HER2 receptor. Oncogene 1999, 18, 305-314. [CrossRef] [PubMed]

69. Howe, L.R.; Subbaramaiah, K.; Chung, W.J.; Dannenberg, A.J.; Brown, A.M.C. Transcriptional activation of cyclooxygenase-2 in Wnt-1-transformed mouse mammary epithelial cells. Cancer Res. 1999, 59, 1572-1577. [PubMed]

70. McAdam, B.F.; Mardini, I.A.; Habib, A.; Burke, A.; Lawson, J.A.; Kapoor, S.; FitzGerald, G.A. Effect of regulated expression of human cyclooxygenase isoforms on eicosanoid and isoeicosanoid production in inflammation. J. Clin. Invest. 2000, 105, 1473-1482 [CrossRef] [PubMed]

71. Attiq, A.; Jalil, J.; Husain, K.; Ahmad, W. Raging the war against inflammation with natural products. Front. Pharmacol. 2018, 9, 976. [CrossRef] [PubMed]

72. Balkwill, F.; Charles, K.A.; Mantovani, A. Smoldering and polarized inflammation in the initiation and promotion of malignant disease. Cancer Cell 2005, 7, 211-217. [CrossRef] [PubMed]

73. Nathan, C. Points of control in inflammation. Nature 2002, 420, 846-852. [CrossRef]

74. Coussens, L.M.; Werb, Z. Inflammation and cancer. Nature 2002, 420, 860-867. [CrossRef]

75. Yang, Y.; Ren, L.; Yang, H.; G, B.; Li, W.; Wang, Y.; Wang, H.; Du, G.; Tang, B.; Wang, J. Research progress on anti-angiogenesis drugs in hepatocellular carcinoma. Cancer Plus 2021, 3, S1. [CrossRef]

76. Wang, Z.; Dai, H.; Su, H.; Lai, S.; Dai, L.; Liu, X.; Wang, Y.; Shu, G.; Tang, B.; Li, Y. Research progress on the role of enzymes involved in histone methylation in hepatocellular carcinoma. Cancer Plus 2021, 2, S1.

77. Raja, S.A.; Ashraf, M.; Anjum, A.A.; Javeed, A.; Ijaz, T.; Attiq, A. Antibacterial activity of essential oils extracted from medicinal plants against multi-drug resistant Staphylococcus aureus. J. Anim. Plant. Sci. 2016, 26, 415-423.

78. Yadav, V.R.; Prasad, S.; Sung, B.; Kannappan, R.; Aggarwal, B.B. Targeting inflammatory pathways by triterpenoids for prevention and treatment of cancer. Toxins 2010, 2, 2428-2466. [CrossRef] [PubMed]

79. Gonçalves, S.M.; Silva, G.N.; Pitta, I.D.; Rêgo, M.J.; Gnoato, S.C.; Pitta, M.G. Novel betulin derivatives inhibit IFN- $\gamma$ and modulates COX-2 expression. Nat. Prod. Res. 2020, 34, 1702-1711. [CrossRef]

80. Viji, V.; Helen, A.; Luxmi, V.R. Betulinic acid inhibits endotoxin-stimulated phosphorylation cascade and pro-inflammatory prostaglandin E2 production in human peripheral blood mononuclear cells. Br. J. Pharmacol. 2011, 162, 1291-1303. [CrossRef]

81. Lin, C.K.; Tseng, C.K.; Chen, K.H.; Wu, S.H.; Liaw, C.C.; Lee, J.C. Betulinic acid exerts anti-hepatitis C virus activity via the suppression of NF-KB- and MAPK-ERK1/2-mediated COX-2 expression. Br. J. Pharmacol. 2015, 172, 4481-4492. [CrossRef]

82. Jalil, J.; Sabandar, C.W.; Ahmat, N.; Jamal, J.A.; Jantan, I.; Aladdin, N.A.; Muhammad, K.; Buang, F.; Mohamad, H.F.; Sahidin, I. Inhibitory effect of triterpenoids from Dillenia serrata (Dilleniaceae) on prostaglandin e2 production and quantitative HPLC analysis of its koetjapic acid and betulinic acid contents. Molecules 2015, 20, 3206-3220. [CrossRef]

83. Zhang, H.; Davies, K.J.A.; Forman, H.J. Oxidative stress response and Nrf2 signaling in aging. Free Radic. Biol. Med. 2015, 88, 314-336. [CrossRef]

84. De la Vega, M.R.; Dodson, M.; Gross, C.; Mansour, H.M.; Lantz, R.C.; Chapman, E.; Wang, T.; Black, S.M.; Garcia, J.G.N.; Zhang, D.D. Role of Nrf2 and autophagy in acute lung injury. Curr. Pharmacol. Rep. 2016, 2, 91-101. [CrossRef] [PubMed]

85. Raghunath, A.; Sundarraj, K.; Arfuso, F.; Sethi, G.; Perumal, E. Dysregulation of Nrf2 in hepatocellular carcinoma: Role in cancer progression and chemoresistance. Cancers 2018, 10, 481. [CrossRef]

86. Wakabayashi, N.; Slocum, S.L.; Skoko, J.J.; Shin, S.; Kensler, T.W. When NRF2 talks, who's listening? Antioxid. Redox Signal. 2010, 13, 1649-1663. [CrossRef]

87. Cebula, M.; Schmidt, E.E.; Arnér, E.S.J. TrxR1 as a potent regulator of the Nrf2-Keap1 response system. Antioxid. Redox Signal. 2015, 23, 823-853. [CrossRef] [PubMed]

88. Carling, D.; Thornton, C.; Woods, A.; Sanders, M.J. AMP-activated protein kinase: New regulation, new roles? Biochem. J. 2012, 445, 11-27. [CrossRef]

89. Xing, H.Y.; Cai, Y.Q.; Wang, X.F.; Wang, L.L.; Li, P.; Wang, G.Y.; Chen, J.H. The cytoprotective effect of hyperoside against oxidative stress is mediated by the Nrf2-ARE signaling pathway through GSK-3ß inactivation. PLoS ONE 2015, 10, e0145183. [CrossRef] [PubMed]

90. Zhang, J.; Zhou, B.; Sun, J.; Chen, H.; Yang, Z. Betulin ameliorates 7,12-dimethylbenz(a)anthracene-induced rat mammary cancer by modulating MAPK and AhR/Nrf-2 signaling pathway. J. Biochem. Mol. Toxicol. 2021, 35, e22779. [CrossRef] [PubMed]

91. Ci, X.; Zhou, J.; Lv, H.; Yu, Q.; Peng, L.; Hua, S. Betulin exhibits anti-inflammatory activity in lps-stimulated macrophages and endotoxin-shocked mice through an ampk/akt/nrf2-dependent mechanism. Cell Death Dis. 2017, 8, e2798. [CrossRef] [PubMed]

92. Loboda, A.; Rojczyk-Golebiewska, E.; Bednarczyk-Cwynar, B.; Zaprutko, L.; Jozkowicz, A.; Dulak, J. Targeting Nrf2-mediated gene transcription by triterpenoids and their derivatives. Biomol. Ther. 2012, 20, 499-505. [CrossRef] [PubMed] 
93. Bai, Y.Y.; Yan, D.; Zhou, H.Y.; Li, W.X.; Lou, Y.Y.; Zhou, X.R.; Qian, L.B.; Xiao, C. Betulinic acid attenuates lipopolysaccharideinduced vascular hyporeactivity in the rat aorta by modulating $\mathrm{Nrf2}$ antioxidative function. Inflammopharmacology 2020, 28, 165-174. [CrossRef]

94. Kong, X.; Thimmulappa, R.; Kombairaju, P.; Biswal, S. NADPH oxidase-dependent reactive oxygen species mediate amplified TLR4 signaling and sepsis-induced mortality in Nrf2-deficient mice. J. Immunol. 2010, 185, 569-577. [CrossRef]

95. Kobayashi, E.H.; Suzuki, T.; Funayama, R.; Nagashima, T.; Hayashi, M.; Sekine, H.; Tanaka, N.; Moriguchi, T.; Motohashi, H.; Nakayama, K.; et al. Nrf2 suppresses macrophage inflammatory response by blocking proinflammatory cytokine transcription. Nat. Commun. 2016, 7, 11624. [CrossRef] [PubMed]

96. Kirtonia, A.; Sethi, G.; Garg, M. The multifaceted role of reactive oxygen species in tumorigenesis. Cell. Mol. Life Sci. 2020, 77, 4459-4483. [CrossRef]

97. Cuadrado, A.; Pajares, M.; Benito, C.; Jiménez-Villegas, J.; Escoll, M.; Fernández-Ginés, R.; Garcia Yagüe, A.J.; Lastra, D.; Manda, G.; Rojo, A.I.; et al. Can activation of NRF2 be a strategy against COVID-19? Trends Pharmacol. Sci. 2020, 41, 598-610. [CrossRef] [PubMed]

98. Hassan, S.M.; Jawad, M.J.; Ahjel, S.W.; Singh, R.B.; Singh, J.; Awad, S.M.; Hadi, N.R. The Nrf2 activator (DMF) and Covid-19: Is there a possible role? Med. Arch. 2020, 74, 134-138. [CrossRef]

99. Gomez, J.C.; Dang, H.; Martin, J.R.; Doerschuk, C.M. Nrf2 Modulates host defense during streptococcus pneumoniae pneumonia in mice. J. Immunol. 2016, 197, 2864-2879. [CrossRef]

100. Staitieh, B.S.; Ding, L.; Neveu, W.A.; Spearman, P.; Guidot, D.M.; Fan, X. HIV-1 decreases Nrf2/ARE activity and phagocytic function in alveolar macrophages. J. Leukoc. Biol. 2017, 102, 517-525. [CrossRef]

101. Ali, M.; Bonay, M.; Vanhee, V.; Vinit, S.; Deramaudt, T.B. Comparative effectiveness of 4 natural and chemical activators of Nrf2 on inflammation, oxidative stress, macrophage polarization, and bactericidal activity in an in vitro macrophage infection model. PLoS ONE 2020, 15, e0234484. [CrossRef]

102. Iddir, M.; Brito, A.; Dingeo, G.; Del Campo, S.S.F.; Samouda, H.; La Frano, M.R.; Bohn, T. Strengthening the immune system and reducing inflammation and oxidative stress through diet and nutrition: Considerations during the covid-19 crisis. Nutrients 2020, 12, 1562. [CrossRef]

103. Bousquet, J.; Cristol, J.P.; Czarlewski, W.; Anto, J.M.; Martineau, A.; Haahtela, T.; Fonseca, S.C.; Iaccarino, G.; Blain, H.; Fiocchi, A.; et al. Nrf2-interacting nutrients and COVID-19: Time for research to develop adaptation strategies. Clin. Transl. Allergy 2020, 10, 58. [CrossRef] [PubMed]

104. Shafabakhsh, R.; Asemi, Z. Quercetin: A natural compound for ovarian cancer treatment. J. Ovarian Res. 2019, 12, 55. [CrossRef]

105. Esposito, S.; Bianco, A.; Russo, R.; Di Maro, A.; Isernia, C.; Pedone, P.V. Therapeutic perspectives of molecules from urtica dioica extracts for cancer treatment. Molecules 2019, 24, 2753. [CrossRef] [PubMed]

106. Imran, M.; Salehi, B.; Sharifi-Rad, J.; Gondal, T.A.; Saeed, F.; Imran, A.; Shahbaz, M.; Fokou, P.V.T.; Arshad, M.U.; Khan, H.; et al. Kaempferol: A key emphasis to its anticancer potential. Molecules 2019, 24, 2277. [CrossRef]

107. Tay, K.-C.; Tan, L.T.-H.; Chan, C.K.; Hong, S.L.; Chan, K.-G.; Yap, W.H.; Pusparajah, P.; Lee, L.-H.; Goh, B.-H. Formononetin: A review of its anticancer potentials and mechanisms. Front. Pharmacol. 2019, 10, 820. [CrossRef]

108. Man, S.; Gao, W.; Zhang, Y.; Huang, L.; Liu, C. Chemical study and medical application of saponins as anti-cancer agents. Fitoterapia 2010, 81, 703-714. [CrossRef] [PubMed]

109. Novío, S.; Cartea, M.E.; Soengas, P.; Freire-Garabal, M.; Núñez-Iglesias, M.J. Effects of brassicaceae isothiocyanates on prostate cancer. Molecules 2016, 21, 626. [CrossRef]

110. Pulido-Moran, M.; Moreno-Fernandez, J.; Ramirez-Tortosa, C.; Ramirez-Tortosa, M.C. Curcumin and health. Molecules 2016, 21, 264. [CrossRef]

111. Barboza, J.N.; da Silva Maia Bezerra Filho, C.; Silva, R.O.; Medeiros, J.V.R.; de Sousa, D.P. An overview on the anti-inflammatory potential and antioxidant profile of eugenol. Oxid. Med. Cell. Longev. 2018, 2018, 3957262. [CrossRef]

112. Azab, A.; Nassar, A.; Azab, A.N. Anti-inflammatory activity of natural products. Molecules 2016, 21, 1321. [CrossRef] [PubMed]

113. Buhrmann, C.; Kunnumakkara, A.B.; Kumar, A.; Samec, M.; Kubatka, P.; Aggarwal, B.B.; Shakibaei, M. Multitargeting effects of calebin a on malignancy of CRC cells in multicellular tumor microenvironment. Front. Oncol. 2021, 11, 650603. [CrossRef] [PubMed]

114. Buhrmann, C.; Shayan, P.; Brockmueller, A.; Shakibaei, M. Resveratrol suppresses cross-talk between colorectal cancer cells and stromal cells in multicellular tumor microenvironment: A bridge between in vitro and in vivo tumor microenvironment study. Molecules 2020, 25, 4292. [CrossRef]

115. Buhrmann, C.; Kraehe, P.; Lueders, C.; Shayan, P.; Goel, A.; Shakibaei, M. Curcumin suppresses crosstalk between colon cancer stem cells and stromal fibroblasts in the tumor microenvironment: Potential role of EMT. PLoS ONE 2014, 9, e107514. [CrossRef]

116. Kim, S.M.; Lee, J.H.; Sethi, G.; Kim, C.; Baek, S.H.; Nam, D.; Chung, W.S.; Kim, S.H.; Shim, B.S.; Ahn, K.S. Bergamottin, a natural furanocoumarin obtained from grapefruit juice induces chemosensitization and apoptosis through the inhibition of STAT3 signaling pathway in tumor cells. Cancer Lett. 2014, 354, 153-163. [CrossRef]

117. Sethi, G.; Shanmugam, M.K.; Warrier, S.; Merarchi, M.; Arfuso, F.; Kumar, A.P.; Bishayee, A. Pro-apoptotic and anti-cancer properties of diosgenin: A comprehensive and critical review. Nutrients 2018, 10, 645. [CrossRef]

118. Aggarwal, V.; Tuli, H.S.; Kaur, J.; Aggarwal, D.; Parashar, G.; Parashar, N.C.; Kulkarni, S.; Kaur, G.; Sak, K.; Kumar, M.; et al. Garcinol exhibits anti-neoplastic effects by targeting diverse oncogenic factors in tumor cells. Biomedicines 2020, 8, 103. [CrossRef] 
119. Tuli, H.S.; Kashyap, D.; Sharma, A.K.; Sandhu, S.S. Molecular aspects of melatonin (MLT)-mediated therapeutic effects. Life Sci. 2015, 135, 147-157. [CrossRef] [PubMed]

120. Zhang, J.; Ahn, K.S.; Kim, C.; Shanmugam, M.K.; Siveen, K.S.; Arfuso, F.; Samym, R.P.; Deivasigamanim, A.; Lim, L.H.K.; Wang, L.; et al. Nimbolide-induced oxidative stress abrogates STAT3 signaling cascade and inhibits tumor growth in transgenic adenocarcinoma of mouse prostate model. Antioxid. Redox Signal. 2016, 24, 575-589. [CrossRef]

121. Kim, C.; Lee, S.G.; Yang, W.M.; Arfuso, F.; Um, J.Y.; Kumar, A.P.; Bian, J.; Sethi, G.; Ahn, K.S. Formononetin-induced oxidative stress abrogates the activation of STAT3/5 signaling axis and suppresses the tumor growth in multiple myeloma preclinical model. Cancer Lett. 2018, 431, 123-141. [CrossRef]

122. Li, F.; Shanmugam, M.K.; Siveen, K.S.; Wang, F.; Ong, T.H.; Loo, S.Y.; Swamy, M.M.M.; Mandal, S.; Kumar, A.P.; Goh, B.C.; et al. Garcinol sensitizes human head and neck carcinoma to cisplatin in a xenograft mouse model despite downregulation of proliferative biomarkers. Oncotarget 2015, 6, 5147-5163. [CrossRef] [PubMed]

123. Soica, C.; Danciu, C.; Savoiu-Balint, G.; Borcan, F.; Ambrus, R.; Zupko, I.; Bojin, F.; Coricovac, D.; Ciurlea, S.; Avram, S.; et al. Betulinic acid in complex with a gamma-cyclodextrin derivative decreases proliferation and in vivo tumor development of non-metastatic and metastatic B164A5 cells. Int. J. Mol. Sci. 2014, 15, 8235-8255. [CrossRef]

124. Bache, M.; Bernhardt, S.; Passin, S.; Wichmann, H.; Hein, A.; Zschornak, M.; Kappler, M.; Taubert, H.; Paschke, R.; Vordermark, D. Betulinic acid derivatives NVX-207 and B10 for treatment of glioblastoma-An in vitro study of cytotoxicity and radiosensitization. Int. J. Mol. Sci. 2014, 15, 19777-19790. [CrossRef] [PubMed]

125. Selzer, E.; Pimentel, E.; Wacheck, V.; Schlegel, W.; Pehamberger, H.; Jansen, B.; Kodym, R. Effects of betulinic acid alone and in combination with irradiation in human melanoma cells. J. Invest. Dermatol. 2000, 114, 935-940. [CrossRef] [PubMed]

126. Eder-Czembirek, C.; Erovic, B.M.; Czembirek, C.; Brunner, M.; Selzer, E.; Pötter, R.; Thurnher, D. Betulinic acid a radiosensitizer in head and neck squamous cell carcinoma cell lines. Strahlenther. Onkol. 2010, 186, 143-148. [CrossRef]

127. Wang, Y.J.; Liu, J.B.; Dou, Y.C. Sequential treatment with betulinic acid followed by 5-fluorouracil shows synergistic cytotoxic activity in ovarian cancer cells. Int. J. Clin. Exp. Pathol. 2015, 8, 252-259. [PubMed]

128. Xu, Y.; Li, J.; Li, Q.J.; Feng, Y.L.; Pan, F. Betulinic acid promotes TRAIL function on liver cancer progression inhibition through p53/Caspase-3 signaling activation. Biomed. Pharmacother. 2017, 88, 349-358. [CrossRef] [PubMed]

129. Cai, Y.; Zheng, Y.; Gu, J.; Wang, S.; Wang, N.; Yang, B.; Zhang, F.; Wang, D.; Fu, W.; Wang, Z. Betulinic acid chemosensitizes breast cancer by triggering ER stress-mediated apoptosis by directly targeting GRP78 article. Cell Death Dis. 2018, 9, 636. [CrossRef] [PubMed]

130. Li, Q.; Li, Y.; Wang, X.; Fang, X.; He, K.; Guo, X.; Zhan, Z.; Sun, C.; Jin, Y.H. Co-treatment with ginsenoside Rh2 and betulinic acid synergistically induces apoptosis in human cancer cells in association with enhanced capsase-8 activation, bax translocation, and cytochrome c release. Mol. Carcinog. 2011, 50, 760-769. [CrossRef]

131. Yamai, H.; Sawada, N.; Yoshida, T.; Seike, J.; Takizawa, H.; Kenzaki, K.; Miyoshi, T.; Kondo, K.; Bando, Y.; Ohnishi, Y.; et al. Triterpenes augment the inhibitory effects of anticancer drugs on growth of human esophageal carcinoma cells in vitro and suppress experimental metastasis in vivo. Int. J. Cancer 2009, 125, 952-960. [CrossRef] [PubMed]

132. Kashyap, D.; Tuli, H.S.; Yerer, M.B.; Sharma, A.; Sak, K.; Srivastava, S.; Pandey, A.; Garg, V.K.; Sethi, G.; Bishayee, A. Natural product-based nanoformulations for cancer therapy: Opportunities and challenges. Semin. Cancer Biol. 2021, 69, 5-23. [CrossRef] [PubMed]

133. Nasery, M.M.; Abadi, B.; Poormoghadam, D.; Zarrabi, A.; Keyhanvar, P.; Khanbabaei, H.; Ashrafizadeh, M.; Mohammadinejad, R.; Tavakol, S.; Sethi, G. Curcumin delivery mediated by bio-based nanoparticles: A review. Molecules 2020, 25, 689. [CrossRef] [PubMed]

134. Mullauer, F.B.; Van Bloois, L.; Daalhuisen, J.B.; Ten Brink, M.S.; Storm, G.; Medema, J.P.; Schiffelers, R.M.; Kessler, J.H. Betulinic acid delivered in liposomes reduces growth of human lung and colon cancers in mice without causing systemic toxicity. Anticancer. Drugs 2011, 22, 223-233. [CrossRef]

135. Liu, Y.; Gao, D.; Zhang, X.; Liu, Z.; Dai, K.; Ji, B.; Wang, Q.; Luo, L. Antitumor drug effect of betulinic acid mediated by polyethylene glycol modified liposomes. Mater. Sci. Eng. C 2016, 64, 124-132. [CrossRef]

136. Shu, Q.; Wu, J.; Chen, Q. Synthesis, characterization of liposomes modified with biosurfactant MEL-A loading betulinic acid and its anticancer effect in HepG2 cell. Molecules 2019, 24, 3939. [CrossRef]

137. Qi, X.; Gao, C.; Yin, C.; Fan, J.; Wu, X.; Guo, C. Improved anticancer activity of betulinic acid on breast cancer through a grafted copolymer-based micelles system. Drug Deliv. 2021, 28, 1962-1971. [CrossRef]

138. Dehelean, C.A.; Feflea, S.; Gheorgheosu, D.; Ganta, S.; Cimpean, A.M.; Muntean, D.; Amiji, M.M. Anti-angiogenic and anticancer evaluation of betulin nanoemulsion in chicken chorioallantoic membrane and skin carcinoma in Balb/c mice. J. Biomed. Nanotechnol. 2013, 9, 577-589. [CrossRef]

139. Tan, J.M.; Karthivashan, G.; Abd Gani, S.; Fakurazi, S.; Hussein, M.Z. Biocompatible polymers coated on carboxylated nanotubes functionalized with betulinic acid for effective drug delivery. J. Mater. Sci. Mater. Med. 2016, 27, 1-12. [CrossRef] [PubMed]

140. Şoica, C.; Dehelean, C.; Danciu, C.; Wang, H.M.; Wenz, G.; Ambrus, R.; Bojin, F.; Anghel, M. Betulin complex in $\gamma$-cyclodextrin derivatives: Properties and antineoplasic activities in in vitro and in vivo tumor models. Int. J. Mol. Sci. 2012, 13, 14992-15011. [CrossRef] [PubMed] 
141. Urandur, S.; Banala, V.T.; Shukla, R.P.; Gautam, S.; Marwaha, D.; Rai, N.; Sharma, M.; Sharma, S.; Ramarao, P.; Mishra, P.R. Theranostic lyotropic liquid crystalline nanostructures for selective breast cancer imaging and therapy. Acta Biomater. 2020, 113, 522-540. [CrossRef]

142. Kumar, P.; Singh, A.K.; Raj, V.; Rai, A.; Keshari, A.K.; Kumar, D.; Maity, B.; Prakash, A.; Maiti, S.; Saha, S. Poly(Lactic-co-glycolic acid)-loaded nanoparticles of betulinic acid for improved treatment of hepatic cancer: Characterization, in vitro and in vivo evaluations. Int. J. Nanomed. 2018, 13, 975-990. [CrossRef]

143. Pinzaru, I.; Sarau, C.; Coricovac, D.; Marcovici, I.; Utescu, C.; Tofan, S.; Popovici, R.A.; Manea, H.C.; Pavel, I.E.; Soica, C.; et al. Article silver nanocolloids loaded with betulinic acid with enhanced antitumor potential: Physicochemical characterization and in vitro evaluation. Nanomaterials 2021, 11, 152. [CrossRef] [PubMed]

144. Kambhampati, N.S.V.; Kar, S.; Pinnepalli, S.S.K.; Chelli, J.; Doble, M. Microbial cyclic $\beta-(1 \rightarrow 3),(1 \rightarrow 6)$-glucans as potential drug carriers: Interaction studies between cyclic $\beta$-glucans isolated from Bradyrhizobium japonicum and betulinic acid. Spectrochim. Acta Part. A Mol. Biomol. Spectrosc. 2018, 203, 494-500. [CrossRef]

145. Kirtonia, A.; Gala, K.; Fernandes, S.G.; Pandya, G.; Pandey, A.K.; Sethi, G.; Khattar, E.; Garg, M. Repurposing of drugs: An attractive pharmacological strategy for cancer therapeutics. Semin. Cancer Biol. 2021, 68, 258-278. [CrossRef] [PubMed]

146. Merarchi, M.; Sethi, G.; Shanmugam, M.K.; Fan, L.; Arfuso, F.; Ahn, K.S. Role of natural products in modulating histone deacetylases in cancer. Molecules 2019, 24, 1047. [CrossRef] [PubMed]

147. Jäger, S.; Laszczyk, M.N.; Scheffler, A. A preliminary pharmacokinetic study of betulin, the main pentacyclic triterpene from extract of outer bark of birch (Betulae alba cortex). Molecules 2008, 13, 3224-3235. [CrossRef]

148. Yoshida, E.H.; Tribuiani, N.; Sabadim, G.; Moreno, D.A.N.; Varanda, E.A.; Oshima-Franco, Y. Evaluation of betulin mutagenicity by Salmonella/microsome test. Adv. Pharm. Bull. 2016, 6, 443-447. [CrossRef]

149. Pflugfelder, A.; Andonov, E.; Weide, B.; Dirschka, T.; Schempp, C.; Stockfleth, E.; Stratigos, A.; Krüger-Krasagakis, S.; Bauer, J.; Garbe, C.; et al. Lack of activity of betulin-based Oleogel-S10 in the treatment of actinic keratoses: A randomized, multicentre, placebo-controlled double-blind phase II trial. Br. J. Dermatol. 2015, 172, 926-932. [CrossRef]

150. Schwieger-Briel, A.; Kiritsi, D.; Schempp, C.; Has, C.; Schumann, H. Betulin-based oleogel to improve wound healing in dystrophic epidermolysis bullosa: A prospective controlled proof-of-concept study. Dermatol. Res. Pract. 2017, 2017. [CrossRef]

151. Frew, Q.; Rennekampff, H.O.; Dziewulski, P.; Moiemen, N.; Zahn, T.; Hartmann, B. Betulin wound gel accelerated healing of superficial partial thickness burns: Results of a randomized, intra-individually controlled, phase III trial with 12-months follow-up. Burns 2019, 45, 876-890. [CrossRef] [PubMed]

152. Małaczewska, J.; Kaczorek-Łukowska, E.; Kazuń, B. High cytotoxicity of betulin towards fish and murine fibroblasts: Is betulin safe for nonneoplastic cells? BMC Vet. Res. 2021, 17, 198. [CrossRef]

153. Laiolo, J.; Barbieri, C.L.; Joray, M.B.; Lanza, P.A.; Palacios, S.M.; Vera, D.M.A.; Carpinella, M.C. Plant extracts and betulin from Ligaria cuneifolia inhibit P-glycoprotein function in leukemia cells. Food Chem. Toxicol. 2021, 147, 111922. [CrossRef]

154. Król, S.K.; Bębenek, E.; Sławińska-Brych, A.; Dmoszyńska-Graniczka, M.; Boryczka, S.; Stepulak, A. Synthetic betulin derivatives inhibit growth of glioma cells in Vitro. Anticancer Res. 2020, 40, 6151-6158. [CrossRef] [PubMed]

155. Lin, Y.C.; Chen, H.Y.; Hsieh, C.P.; Huang, Y.F.; Chang, I.L. Betulin inhibits mTOR and induces autophagy to promote apoptosis in human osteosarcoma cell lines. Environ. Toxicol. 2020, 35, 879-887. [CrossRef]

156. Shen, H.; Liu, L.; Yang, Y.; Xun, W.; Wei, K.; Zeng, G. Betulinic acid inhibits cell proliferation in human Oral squamous cell carcinoma via modulating ROS-regulated p53 signaling. Oncol. Res. 2017, 25, 1141-1152. [CrossRef]

157. Kadela-Tomanek, M.; Bębenek, E.; Chrobak, E.; Marciniec, K.; Latocha, M.; Kuśmierz, D.; Jastrzębska, M.; Boryczka, S. Betulin1,4-quinone hybrids: Synthesis, anticancer activity and molecular docking study with NQO1 enzyme. Eur. J. Med. Chem. 2019, 177, 302-315. [CrossRef]

158. Pfarr, K.; Danciu, C.; Arlt, O.; Neske, C.; Dehelean, C.; Pfeilschifter, J.M.; Radeke, H.H. Simultaneous and dose dependent melanoma cytotoxic and immune stimulatory activity of betulin. PLoS ONE 2015, 10, e0118802. [CrossRef] [PubMed]

159. Drag-Zalesińska, M.; Wysocka, T.; Borska, S.; Drag, M.; Poreba, M.; Choromańska, A.; Kulbacka, J.; Saczko, J. The new esters derivatives of betulin and betulinic acid in epidermoid squamous carcinoma treatment-In vitro studies. Biomed. Pharmacother. 2015, 72, 91-97. [CrossRef]

160. John, R.; Dalal, B.; Shankarkumar, A.; Devarajan, P.V. Innovative Betulin Nanosuspension exhibits enhanced anticancer activity in a Triple Negative Breast Cancer Cell line and Zebrafish angiogenesis model. Int. J. Pharm. 2021, 600, 120511. [CrossRef] [PubMed]

161. Zheng, Y.; Liu, P.; Wang, N.; Wang, S.; Yang, B.; Li, M.; Chen, J.; Situ, H.; Xie, M.; Lin, Y.; et al. Betulinic acid suppresses breast cancer metastasis by targeting GRP78-mediated glycolysis and ER stress apoptotic pathway. Oxid. Med. Cell. Longev. 2019, 2019, 8781690. [CrossRef] [PubMed]

162. Dehelean, C.A.; Feflea, S.; Molnár, J.; Zupko, I.; Soica, C. Betulin as an antitumor agent tested in vitro on A431, HeLa and MCF7, and as an angiogenic inhibitor in vivo in the CAM assay. Nat. Prod. Commun. 2012, 7, 981-985. [CrossRef] [PubMed]

163. Kıran, İ.; Çiftçi, G.A.; Eklioğlu, Ö.A.; Akkaya, Ş.G.K. Bacterial biotransformation and anticancer activities of betulin against A549, HepG2 and 5RP7 cancer cell lines. Anticancer. Agents Med. Chem. 2020, 21, 1581-1593. [CrossRef]

164. Zhao, H.; Mu, X.; Zhang, X.; You, Q. Lung cancer inhibition by betulinic acid nanoparticles via adenosine 5'-Triphosphate (ATP)-binding cassette transporter G1 gene downregulation. Med. Sci. Monit. 2020, 26, e922092. [CrossRef] 
165. Zehra, B.; Ahmed, A.; Sarwar, R.; Khan, A.; Farooq, U.; Ali, S.A.; Al-Harrasi, A. Apoptotic and antimetastatic activities of betulin isolated from Quercus incana against non-small cell lung cancer cells. Cancer Manag. Res. 2019, 11, 1667-1683. [CrossRef] [PubMed]

166. Jae, S.P.; Si, H.R.; Dae, K.K.; Jin, G.L.; Yong, Y.L.; Soon, S.H.; Sung, W.K.; Jeong, H.P. Anti-cancer effect of betulin on a human lung cancer cell line: A pharmacoproteomic approach using 2 D SDS PAGE coupled with nano-HPLC tandem mass spectrometry. Planta Med. 2009, 75, 127-131. [CrossRef]

167. Chen, X.; Yuan, X.; Zhang, Z.; Gong, P.; Yin, W.; Jiang, Q.; Xu, J.; Xu, X.; Gao, Y.; Chen, W.; et al. Betulinic acid inhibits cell proliferation and migration in gastric cancer by targeting the NF-кB/VASP pathway. Eur. J. Pharmacol. 2020, 889, 173493. [CrossRef] [PubMed]

168. Kim, S.Y.; Hwangbo, H.; Kim, M.Y.; Ji, S.Y.; Kim, D.H.; Lee, H.; Kim, G.Y.; Moon, S.K.; Leem, S.H.; Yun, S.J.; et al. Betulinic acid restricts human bladder cancer cell proliferation in vitro by inducing caspase-dependent cell death and cell cycle arrest, and decreasing metastatic potential. Molecules 2021, 26, 1381. [CrossRef] [PubMed]

169. Zhou, Z.; Zhu, C.; Cai, Z.; Zhao, F.; He, L.; Lou, X.; Qi, X. Betulin induces cytochrome c release and apoptosis in colon cancer cells via NOXA. Oncol. Lett. 2018, 15, 7319-7327. [CrossRef] [PubMed]

170. Sun, L.; Cao, J.; Chen, K.; Cheng, L.; Zhou, C.; Yan, B.; Qian, W.; Li, J.; Duan, W.; Ma, J.; et al. Betulinic acid inhibits stemness and EMT of pancreatic cancer cells via activation of AMPK signaling. Int. J. Oncol. 2019, 54, 98-110. [CrossRef]

171. Wang, W.; Wang, Y.; Liu, M.; Zhang, Y.; Yang, T.; Li, D.; Huang, Y.; Li, Q.; Bai, G.; Shi, L. Betulinic acid induces apoptosis and suppresses metastasis in hepatocellular carcinoma cell lines in vitro and in vivo. J. Cell. Mol. Med. 2019, 23, 586-595. [CrossRef] [PubMed]

172. Yang, C.; Li, Y.; Fu, L.; Jiang, T.; Meng, F. Betulinic acid induces apoptosis and inhibits metastasis of human renal carcinoma cells in vitro and in vivo. J. Cell. Biochem. 2018, 119, 8611-8622. [CrossRef] [PubMed]

173. Cheng, W.; Ji, S.; Zhang, H.; Han, Z.; Liu, Q.; Wang, J.; Ping, H. mTOR activation is critical for betulin treatment in renal cell carcinoma cells. Biochem. Biophys. Res. Commun. 2017, 482, 1030-1036. [CrossRef]

174. Yim, N.H.; Jung, Y.P.; Kim, A.; Kim, T.; Ma, J.Y. Induction of apoptotic cell death by betulin in multidrug-resistant human renal carcinoma cells. Oncol. Rep. 2015, 34, 1058-1064. [CrossRef]

175. Härmä, V.; Haavikko, R.; Virtanen, J.; Ahonen, I.; Schukov, H.P.; Alakurtti, S.; Purev, E.; Rischer, H.; Yli-Kauhaluoma, J.; Moreira, V.M.; et al. Optimization of invasion-specific effects of betulin derivatives on prostate cancer cells through lead development. PLoS ONE 2015, 10, e0126111. [CrossRef] [PubMed]

176. Liao, L.; Liu, C.; Xie, X.; Zhou, J. Betulinic acid induces apoptosis and impairs migration and invasion in a mouse model of ovarian cancer. J. Food Biochem. 2020, 44, e13278. [CrossRef] [PubMed]

177. Lee, D.; Lee, S.R.; Kang, K.S.; Ko, Y.; Pang, C.; Yamabe, N.; Kim, K.H. Betulinic acid suppresses ovarian cancer cell proliferation through induction of apoptosis. Biomolecules 2019, 9, 257. [CrossRef]

178. Kim, H.J.; Cho, H.S.; Ban, H.S.; Nakamura, H. Suppression of HIF- $1 \alpha$ accumulation by betulinic acid through proteasome activation in hypoxic cervical cancer. Biochem. Biophys. Res. Commun. 2020, 523, 726-732. [CrossRef]

179. Weber, L.A.; Meißner, J.; Delarocque, J.; Kalbitz, J.; Feige, K.; Kietzmann, M.; Michaelis, A.; Paschke, R.; Michael, J.; Pratscher, B.; et al. Betulinic acid shows anticancer activity against equine melanoma cells and permeates isolated equine skin in vitro. BMC Vet. Res. 2020, 16, 44. [CrossRef]

180. Zeng, A.; Hua, H.; Liu, L.; Zhao, J. Betulinic acid induces apoptosis and inhibits metastasis of human colorectal cancer cells in vitro and in vivo. Bioorg. Med. Chem. 2019, 27, 2546-2552. [CrossRef]

181. Chen, Y.; Wu, X.; Liu, C.; Zhou, Y. Betulinic acid triggers apoptosis and inhibits migration and invasion of gastric cancer cells by impairing EMT progress. Cell Biochem. Funct. 2020, 38, 702-709. [CrossRef] [PubMed] 